\title{
The relationship between Chief Executive Officer remuneration and financial performance in South Africa between 2006 and 2012
}

\begin{tabular}{|c|c|}
\hline \multicolumn{2}{|c|}{$\begin{array}{l}\text { Authors: } \\
\text { Mark Bussin }{ }^{1} \\
\text { Minute F. Modau }^{2}\end{array}$} \\
\hline $\begin{array}{l}\text { Affiliations: } \\
{ }^{1} \text { Department } \\
\text { Psychology a } \\
\text { Resource Ma } \\
\text { University of } \\
\text { South Africa }\end{array}$ & $\begin{array}{l}\text { of Industrial } \\
\text { d Human } \\
\text { nagement, } \\
\text { ohannesburg, }\end{array}$ \\
\hline $\begin{array}{l}{ }^{2} \text { Gordon Insti } \\
\text { Science, Univ } \\
\text { Pretoria, Sou }\end{array}$ & $\begin{array}{l}\text { ute of Business } \\
\text { ersity of } \\
\text { h Africa }\end{array}$ \\
\hline $\begin{array}{l}\text { Corresponde } \\
\text { Mark Bussin }\end{array}$ & nce to: \\
\hline $\begin{array}{l}\text { Email: } \\
\text { drbussin@m }\end{array}$ & veb.co.za \\
\hline $\begin{array}{l}\text { Postal addre } \\
\text { PO Box } 2334 \\
2132 \text {, South }\end{array}$ & $\begin{array}{l}\text { S: } \\
\text { Saxonwold } \\
\text { frica }\end{array}$ \\
\hline $\begin{array}{l}\text { Dates: } \\
\text { Received: } 06 \\
\text { Accepted: } 12 \\
\text { Published: } 17\end{array}$ & $\begin{array}{l}\text { Oct. } 2014 \\
\text { Mar. } 2015 \\
\text { June } 2015\end{array}$ \\
\hline $\begin{array}{l}\text { How to cite t } \\
\text { Bussin, M., \& } \\
\text { (2015). The } r \\
\text { between Chi } \\
\text { Officer remur } \\
\text { financial perf } \\
\text { in South Afric } \\
2006 \text { and } 201 \\
\text { of Human Re } \\
\text { Managemen } \\
\text { Menslikehulp } \\
\text { 13(1), Art. \#6 } \\
\text { http://dx.doi } \\
\text { sajhrm.v13i1 }\end{array}$ & $\begin{array}{l}\text { is article: } \\
\text { Modau, M.F. } \\
\text { lationship } \\
\text { f Executive } \\
\text { eration and } \\
\text { ormance } \\
\text { a between } \\
\text { 2. SA Journal } \\
\text { ource } \\
\text { SA Tydskrif vir } \\
\text { bronbestuur, } \\
68,18 \text { pages. } \\
\text { org/10.4102/ } \\
668\end{array}$ \\
\hline $\begin{array}{l}\text { Copyright: } \\
\text { (C) 2015. The } \\
\text { Licensee: AO } \\
\text { OpenJournal } \\
\text { licensed und } \\
\text { Commons At } \\
\text { License. }\end{array}$ & $\begin{array}{l}\text { Authors. } \\
\text { Th } \\
\text { This work is } \\
\text { r the Creative } \\
\text { ribution }\end{array}$ \\
\hline 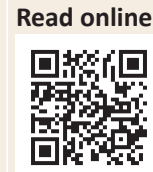 & $\begin{array}{l}\text { Scan this QR } \\
\text { code with your } \\
\text { smart phone or } \\
\text { mobile device } \\
\text { to read online. }\end{array}$ \\
\hline
\end{tabular}

Authors:

Mark Bussin

Affiliations:

${ }^{1}$ Department of Industria

Psychology and Human

urce Management

University of Johannesburg

Science, University of

Correspondence to:

Email:

Postal address:

PO Box 2334, Saxonwold

Dates:

Received: 06 Oct. 2014

Accepted: 12 Mar. 2015

How to cite this article:

Bussin, M., \& Modau, M.

(2015). The relationship

financial performance

in South Africa between

of Human Resource

Management/SA Tydskrif vir Menslikehulpbronbestuur,

13(1), Art. \#668, 18 pages

http://dx.doi.org/10.4102/

Copyright:

(C) 2015. The Authors

Licensee: AOSIS

licensed under the Creative

Commons Attribution

License.
Orientation: The relationship between Chief Executive Officer (CEO) remuneration and organisation performance has been a topic of close scrutiny, especially since the global financial crisis. Optimal contracting relies on the premise that effective incentives will link organisation financial performance and CEO remuneration in ways that will be in the best interests of both shareholders and CEOs.

Research purpose: The purpose of this research study was to investigate the relationship between CEO remuneration and organisation performance in South Africa between 2006 and 2012 and to determine whether the two constructs were positively correlated.

Motivation for the study: The study provides an evidenced-based understanding of the nature of the CEO pay-performance relationship in South Africa. Understanding this relationship is critical to finding a suitable model to structure executive remuneration that will protect shareholders from over-remunerating executives in times of economic appreciation, whilst protecting executives from being underpaid in times of economic depreciation.

Method: The financial results and CEO remuneration of 21 of the top 40 listed companies on the Johannesburg Stock Exchange were analysed for the period 2006-2012. The research was a quantitative, archival study. The primary statistical techniques used in the study were correlation analysis and multiple regression analysis.

Main findings: The primary finding of the current research indicates that between 2006 and 2012 organisation executives have noticeably been moving away from focusing on short-term incentives, which are categorised as performance-related elements of remuneration packages. Based on these findings, it is evident that the relationship between executive remuneration and organisational financial performance has been experiencing a decline, especially since the 2008 global financial crisis. The decline has predominantly been due to a move away from performance-related elements of remuneration contracts by CEOs, creating a disconnect between $\mathrm{CEO}$ remuneration and organisational performance. The findings suggest that, to a large extent, remuneration contracts for CEOs are no longer optimal for the organisation and its shareholders, but are influenced by the propensity of executives to enhance their own remuneration. There exists a link between short-term incentives received by CEOs and accounting-based organisational performance measures; on the other hand, fixed pay linked with organisational performance measures continue to be eroded as organisations' executives become more innovative as they are noticeably moving away from focusing on short-term incentives.

Practical/managerial implications: A stronger test of the pay-performance link and the power of incentive design are required in order to ensure that executives are rewarded or penalised for poor performance. The question of how executives are paid also needs to be considered.

Contribution: This research contributes to the literature on CEO remuneration by providing an evidenced-based understanding of the nature of the CEO pay-performance relationship in South Africa. Understanding this relationship is critical to finding a suitable model to structure executive remuneration that will protect shareholders from over-remunerating executives in times of economic appreciation, whilst protecting executives from being underpaid in times of economic depreciation.

\section{Introduction}

\section{Key focus of the study}

The primary challenge in the executive pay-performance relationship is finding a mutually beneficial balance between executive remuneration and organisational performance. This 
challenge is compounded by the fact that there is no universally accepted understanding of the strength and significance of the relationship. In addition, the measurement of organisational performance is itself open to interpretation with a variety of conflicting indicators suggested as valid and reliable. The lack of clarity in the understanding and measurement of the constructs within the executive payperformance relationship makes the creation of a model to structure executive remuneration difficult. A longitudinal, evidence-based understanding of the relationship between executive pay and organisational performance is necessary to determine a meaningful and optimal model of executive remuneration.

\section{Background to the study}

Chief Executive Officers (CEOs) assume the highest levels of responsibility and accountability for an organisation and its performance on behalf of the organisation's shareholders (Kaplan, 2013; Wibowo \& Kleiner, 2005). These individuals are typically highly skilled, have significant leadership competencies and are viewed as a scarce resource. As a result, these executives are highly incentivised through remuneration structures to remain in the employ of the organisation and drive the performance of the organisation. In order to ensure that there is alignment between the CEO's interests and those of the shareholders it is important for shareholders to design and employ a pay-performance model that is proven to deliver this alignment.

There is a well-recognised challenge in finding a balance between remuneration that will be enticing enough to keep executives in the employ of the organisation without overcompensating them when organisation performance is not favourable (Bebchuk \& Fried, 2005; Marais \& Lefifi, 2013). There have been calls from governments, trade unions and civil society to curb what is perceived as exorbitant executive remuneration in light of increasing levels of relative poverty and inequality, especially in countries like South Africa (Marais \& Lefifi, 2013). The 2008 global financial crisis has placed executive remuneration even more directly in the spotlight due a perceived weak payperformance link.

According to researchers such as Shaw (2011) and Bebchuk, Cohen and Holger (2010), executive remuneration has been widely regarded as one of the key contributors to the financial crisis. This sentiment has found its way into academic literature as researchers try to understand more fully the root causes of the 2008 global financial crisis.

Much criticism has been levelled at organisations and their remuneration committees for increases in executive remuneration in the face of disappointing financial results (Lindqvist \& Grunditz, 2004). The amount of legislation and regulation in dealing with executive remuneration has subsequently increased, supporting remuneration contracts that reward superior organisation performance (Morrissey, 2009).

\section{Research purpose}

In South Africa, the Companies Act (Act No. 71 of 2008) and King Code and Report on Governance in South Africa (King III; Institute of Directors Southern Africa, 2009) specify that there should be a positive correlation between CEO remuneration and organisation performance, and associated disclosure requirements have also increased (Institute of Directors Southern Africa, 2009). The purpose of this research is to investigate whether there is indeed a positive correlation or not between CEO remuneration and company performance, especially in the biggest companies listed on the Johannesburg Stock Exchange.

\section{Trends from the research literature}

There are empirical findings that support both a relationship between CEO pay and organisational performance, as well as little or no relationship. In seminal pieces of research, Jensen and Murphy (1999) found that the correlation was small and that shareholders came off second best. In contrast to this, Firth, Fung and Rui (2006) and Merhebi, Pattenden, Swan and Zhou (2006) found that there was a significant positive correlation between CEO pay and most measures of organisational performance. Most studies show a decline in the relationship between CEO pay and organisational performance since the global financial crisis in 2008 (Shaw, 2011; Van Blerck, 2012; Van Rooyen, Du Toit, Botha \& Rothmann, 2010).

\section{Research objectives}

To facilitate an optimal contract between a CEO and shareholders, the incentives of the CEO need to be aligned with the interests of shareholders, thus creating value for both through the pay-performance relationship (O'Byrne \& Gressle, 2013; Veliyath \& Bishop, 1995). The purpose of this research study was to investigate the relationship between CEO remuneration and organisational performance in South Africa between 2006 and 2012, and to determine whether the two constructs were positively correlated.

The primary research objectives were as follows:

- To establish if there were any structural changes that occurred in South Africa after the 2008 global financial crisis with regard to the mix in the remuneration components received by CEOs.

- To establish the closest link (correlation) between CEO remuneration and financial performance of an organisation when considering the most commonly used financial performance measures.

\section{The potential value-add of the study}

This research contributes to the literature on CEO remuneration by providing an evidenced-based understanding of the nature of the CEO pay-performance relationship in South Africa. Understanding this relationship is critical to finding a suitable model to structure executive 
remuneration that will protect shareholders from overremunerating executives in times of economic appreciation, whilst protecting executives from being underpaid in times of economic depreciation.

Previous research asserts that performance-based elements of CEO remuneration are necessary to justify the high remuneration packages of executives. The research points to the long-term dilemma that will arise for boards of directors if they become reluctant to either reward executives for superior performance or penalise them for poor performance.

\section{What will follow}

A more detailed review of the literature follows in the next section. The research design section outlines the longitudinal, quantitative, archival research method selected and describes the sampling rationale employed. The results of the study are then presented and discussed. The article concludes with a brief discussion of the research limitations and practical implications for remuneration practitioners.

\section{Literature review}

\section{CEO remuneration components}

CEO remuneration is composed of the financial compensation and other non-financial awards received by an executive from their firm for their service to the organisation. The concept of executive remuneration includes all payments made to executive members of the board including the CEO (Bussin, 2011). These payments include all guaranteed costto-company (CTC), short-term and long-term incentives and other financial benefits for performance rendered (Bussin, 2011). Desirable remuneration packages are created to ensure the ability of the company to attract and retain the best possible CEOs. The most common determinants for executive pay are organisation size, organisation performance, executivespecific factors (such as age, experience, tenure, career path), organisation structure, job or position-specific factors and job complexity (Bussin, 2011).

Excessive pay can be seen as additional amounts of money that need to be paid for services and activities that were not originally planned or taken into account. Despite substantial heterogeneity in remuneration practices across different organisations, most CEO remuneration packages consist of salary, annual bonus, short-term and long-term performance incentives (Frydman \& Jenter, 2010; Warr \& Fay, 2001).

Ellig (2007) argues that the structure of an executive's remuneration package will follow the path where it is the easiest for the executive to earn a more favourable remuneration. Should short-term incentives (STIs) be difficult to obtain due to factors outside the control of the $\mathrm{CEO}$, the structure of the remuneration would lean towards a guaranteed CTC or fixed pay (FP). The inverse is also true, that should STIs be easier to obtain, the structure of remuneration will gravitate towards higher incentive pay (Ellig, 2007).

\section{The principal-agent theory}

The principal-agent theory needs to be understood in order to gain an understanding of the executive remuneration process. Laffont and Martimort (2002) argue that the owner of an organisation needs to delegate their responsibilities to other members of the organisation. The owner therefore becomes the principal and the employee becomes the agent. Duffhues and Kabir (2008) state that listed companies are characterised by the ownership of the organisation residing with the shareholders who reflect a diverse and wide cross-section of the population, whilst control is in the hands of a few managers responsible for the management of the organisation. The principal-agent theory infers that these managers or agents do not always perform their jobs solely in the best interests of the shareholders.

Frydman and Jenter (2010) discuss the structure of executive pay as a possible method of rectifying this misalignment between the principal and the agent. Compensation committees are one of the key mechanisms that could assist in aligning the principal and the agent by reviewing CEO compensation with specific attention to goal setting and alignment with incentives. O'Reilly and Main (2010) describe this process as the board crafting an optimal pay mechanism to try and align the interests of the CEO with those of the shareholders. Thus it is clear that the CEO is the agent of the shareholders, who as a group represent the principal and that the agent's goals should be aligned with those of the organisation and the principal.

\section{Remuneration committees}

Organisations should appoint a remuneration committee or other such appropriate board committee, consisting entirely or mainly of independent non-executive directors, to make recommendations regarding executive and CEO pay. The principal-agent theory assumes it is the purpose of the board to monitor the CEO. However, O'Reilly and Main (2010) argue that this is a narrow view of the duties of a board. To minimise the costs associated with this theory, CEO compensation should be linked to both the CEO's performance and the organisation's performance to ensure an alignment between shareholders and management interests (O'Reilly \& Main, 2010). Prior research showed that as the power of the CEO increased, their pay increased; however the sensitivity of their pay to performance decreased (Lin \& Kuo, 2013; O’Reilly \& Main, 2010).

King III (2009) discusses the remuneration committee in detail and adds that it should be the duty of the remuneration committee to assist the board in setting the various salary bands within the organisation, particularly for the remuneration packages of the senior executives. King III (2009) states that remuneration committees should keep the long-term goals of the organisation in mind when giving remuneration advice.

\section{Optimal contracting and the managerial power approach}

Bebchuk and Fried (2003) suggest that there are two contrasting views on the link between the agency problem and 
the remuneration received by executives in an organisation. The optimal contracting approach, which considers executive remuneration as a remedy to the agency problem, is the more widely accepted view. Under the optimal contracting approach 'boards are assumed to design compensation schemes to provide executives with efficient incentives to maximize shareholder value' (Bebchuk \& Fried, 2003, p. 1). This view is also supported by Shaw and Zhang (2010) as they assert that efficient remuneration contracts will link executive remuneration with organisational performance, whilst providing compelling incentives for executives to avoid self-serving activities and operate organisations in the shareholders' best interests.

According to Bebchuk and Fried (2003), optimal remuneration contracts could result from either effective arm's length bargaining between executives and boards of directors, or from market constraints that will encourage executives and boards of directors to adopt such contracts even in the absence of arm's length bargaining. Market constraints consider what executives will ask boards of directors to approve and what boards of directors will agree to.

In contrast to the optimal contracting approach, the managerial power approach considers remuneration received by executives not only as a potential instrument for dealing with agency problems, but also as part of the agency problem (Frydman \& Jenter, 2010). According to Bebchuk, Fried and Walker (2002), remuneration contracts are not only shaped by what would be optimal, but are also influenced by executives' capability to influence their own remuneration contracts. Also, market constraints are not seen to play a significant role in preventing executives from obtaining arrangements that are more favourable to themselves.

According to the managerial power approach, boardapproved executive remuneration contracts often deviate from optimal contracting arrangements. Factors that enable this deviation include: boards of directors being subjected to influence by executives, boards being sympathetic to executives or boards being incompetent in overseeing remuneration contracts (Bebchuk et al., 2002). The result of managerial power is thus a situation in which executives receive rewards in excess of what would be optimal for shareholders. The excess rewards constitute rent extraction rather than the provision of efficient incentives (Bebchuk et al., 2002).

In summary, there are weaknesses in the optimal contracting approach that are highlighted by the managerial power approach. Despite these weaknesses, that the CEO exerts too much power over the negotiation of the remuneration package, it is still widely believed that executive rewards can be used to align the interests of executives to those of the shareholders and thereby reduce possible agency costs (Edmans \& Gabaix, 2009). In addition, even if the CEO's remuneration is efficient due to the optimal contracting approach, it does not preclude remuneration packages from being suboptimal and, as a result, intense scrutiny by shareholders remains important.

\section{Organisation performance measures}

Organisational performance can be measured in many different ways using accounting-based measures and market-based measures (Attaway, 2000). Fatemi, Desai and Katz (2003) argue that such measures do not account for the risk incurred by the organisation's executive in their search for growth and profitability, suggesting two additional measures, namely economic value added (EVA) and market value added (MVA). According to the economic theories of remuneration, 'organisational performance should affect an executive's remuneration only to the extent that it serves as a proxy for unobservable managerial effort or productivity' (Murphy, 1985, p. 20). Although previous theories uniformly suggest a relationship between compensation and observed performance, most analyses are not in agreement with regard to the measurement of organisational performance (Canarella \& Gasparyan, 2008).

In the empirical compensation literature there seems to be limited consensus on the optimal measure of company performance as researchers have measured organisational performance in many different ways (Attaway, 2000; Bacidore, Boquist, Milbourn \& Thakor, 1997; Canarella \& Gasparyan, 2008; Carpenter \& Sanders, 2002; Eriksson \& Lausten, 2000; Fatemi et al., 2003; Kyriazis \& Anastassis, 2007). Measures of company performance can be divided into three main categories: absolute financial performance measures (audited measures within a specific year), financial performance ratios (ratios derived from absolute performance measures) and market performance measures (performance within equity markets) (Edmans, Gabaix, Sadzik \& Sannikov, 2012; Shaw, 2011).

\section{The CEO pay-performance relationship}

Since the early 2000s executive compensation levels have increased dramatically. Managerial power and optimal contracting have been offered as leading reasons for this increase (Frydman \& Jenter, 2010). Optimal contracting is defined as occurring when the three types of agency costs (contracting, monitoring and misbehaviour) are balanced against one another to minimise the total cost (Harvey, 2012). It is suggested that executives have influenced remuneration committees to increase fixed pay (despite poor organisational performance over the financial crisis period) in order to compensate for the loss of shortterm and long-term incentive payouts (Amzaleg, Azar, Ben-Zion \& Rosenfield, 2014; Frydman \& Jenter, 2010). Through managerial power, CEOs are able to influence boards and compensation committees and thus influence the structure of their remuneration packages (Doscher \& Friedl, 2010).

Jensen and Murphy (1999) acknowledge that there are serious problems with executive remuneration, but they do not view excessive CEO pay as the most significant 
issue. They point out that 'the relentless focus on how much CEOs are remunerated diverts public attention from the real problem - how CEOs are paid' (Jensen \& Murphy, 1999, p. 64). Haynes, Thompson and Wright (2007) point out that failure to reward or punish executives for either superior or poor performance will erode the link between CEO remuneration and organisation performance and will, according to Jensen and Murphy (1999), entrench what they call 'bureaucratic remuneration systems' (p. 159). Instead, Anderson and Kleiner (2003) assert that the remuneration of organisations' top executives should be virtually dependent on organisation performance.

Although the theoretical and empirical literature on executive remuneration is fairly well developed, it is far from complete, according to Canarella and Gasparyan (2008). A large number of pay-performance studies have been carried out in most parts of the world, and these studies reflect a lack of consensus on the pay-performance relationship (Abraham, Harris \& Auerbach, 2014; Bruce, Buck \& Main, 2005).

The literature indicates that there is limited consensus on the optimal measure of organisational financial performance as researchers continue to assess organisational performance in many different ways (Attaway, 2000; Bacidore et al., 1997; Chari, 2009; Fatemi et al., 2003). Older research studies use accounting and market-based measures of organisation performance, whilst more recent studies use EVA and MVA. Some researchers, like Canarella and Gasparyan (2008), use both accounting-based and stock market-based measures to avoid potential biases inherent in using either of the two performance measures on their own.

Firth et al. (2006) conducted a CEO pay-performance study in China. Their study, in which they used regression analysis techniques, found that there was a positive relation between $\mathrm{CEO}$ remuneration and organisation performance measured in both accounting and shareholder wealth. Their study results, however, indicate that the relations were only statistically significant under certain ownership conditions. Organisations that have state bureaucratic agencies as the major shareholder did not appear to embrace performancerelated pay schemes. Firth et al.'s regression results indicated that a change in shareholder wealth was positively associated with change in CEO remuneration and the relationship was not significant, that is, in the remuneration-performance equation, the change in shareholders' wealth slope was 0.004 for state-controlled organisations. In contrast, listed organisations with a private block-holder as the largest shareholder based CEO remuneration on changes in shareholder wealth, resulting in the remunerationperformance equation with the change in shareholders' wealth slope of 0.485 .

In contrast to these and other studies which found a positive and significant relationship between CEO pay and organisation performance, Jensen and Murphy (1999) analysed the CEO remuneration of 2505 CEOs in 1400 publicly held organisations from 1974 to 1988 in the US.
They concluded that the relationship between CEO and shareholder wealth was small and had fallen significantly in the last 50 years. Mueller's (2006) study supports this observation by concluding that executive remuneration packages in the US increased by far more than could be accounted for by increases in managerial productivity in the 1990s. The study by Mueller (2006) indicated that using the organisational remuneration-performance relationship derived from 1993 data, CEO remunerations were 215\% higher than predicted by the 1993 estimates.

Another study, conducted in the UK by Haynes et al. (2007), found that organisation size had a positive and significant impact on executive remuneration (in the remunerationperformance equation the slope on organisation size was found to be 0.21 ) and that the responsiveness of executive remuneration to organisation performance was much smaller when compared to the size of the organisation (the slope on organisation performance was found to be 0.12 ). A study by Duffhues and Kabir (2008) found no evidence of a positive pay-performance relationship for executives in the Netherlands, which led to the conclusion that executives in the Netherlands received rewards for reasons unrelated to performance. Duffhues and Kabir's study found that in the pay-performance equation, the regression slope on organisation performance between 1998 and 2001 was between -0.539 and -0.074 , whilst the slope for organisation size between 1998 and 2001 was between 0.399 and 0.413 .

In South Africa, a CEO pay-performance research study by Shaw (2011) looked at financial service organisations during the period 2005 to 2010. Shaw categorised organisation performance measures into three main categories: absolute financial performance measures, financial performance ratios and market performance measures. The study used economic profit, accounting profit and shareholder returns in the form of return on equity (ROE) and headline earnings per share (HEPS) as measures of organisational performance. Debt to assets ratio and total assets or book value were also included to ensure comprehensive measurement of organisational performance.

Shaw (2011) found a moderate to strong relationship between CEO remuneration and organisation performance. However, the results of the study indicated that there has been a decline in the relationship between 2008 and 2012: the average coefficient of correlation scores between organisation performance and book value, earnings before income tax depreciation and appreciation (EBITDA) and profit after tax were found to be $0.56,0.52$ and 0.45 , respectively. The results of the study also showed an associated structural change in the mix of remuneration components, 'most notably there was an observed shift in CEO remuneration from variable pay to fixed pay' (Shaw, 2011, p. 102).

A similar study on South African financial institutions conducted by Van Blerck (2012) used EVA, ROE and share price as the organisation performance measures and considered a time period between 2002 and 2011. Van Blerck's 
findings support those of Shaw (2011), finding a moderate correlation between share price and executive remuneration and only a weak relationship with ROE before 2007. Shaw's study found an average coefficient of correlation of 0.013 between remuneration and ROE, whilst Van Blerck found it to be 0.293 . Van Blerck found that the remuneration received by executives in South African financial institutions correlated strongly with EVA and that the correlation strengthened after the 2008 financial crisis: the coefficient of correlation for EVA between 2002 and 2006 was found to be 0.592 and between 2007 and 2011 it found to be 0.663 . More importantly, Van Blerck also found that executives based in the US have rewards that are strongly aligned to equity-based incentives compared to South African executives, whose rewards are strongly aligned to EVA: the coefficient of correlation for ROE between 2002 and 2006 was found to be 0.067 and between 2007 and 2011 it found to have increased to 0.338 .

\section{Conceptual underpinning of CEO pay-performance relationship}

Whilst CEOs are responsible and accountable for their respective organisations' performance, and are highly incentivised through remuneration structures to ensure they perform their duties solely in the best interest of the shareholders, in recent years CEOs' remunerations have been in the limelight and often for the wrong reasons (Anderson \& Kleiner, 2003; Enrione, Mazza \& Zerboni, 2006; Matsumura \& Shin, 2005; Ozkan, 2011). In view of many national recessions caused by the financial crisis of 2008, the high remuneration packages of executives, especially CEOs, has attracted the attention of the public, unions, investors, the media and academic researchers.

The public continues on the perception that executives receive excessive salaries and bonuses (Leon, 2012). The unions continue to express outrage at large remuneration increases in executives' salaries compared to national average salaries of employees (Mantshantsha, 2007). The investors expect that there should be a close alignment between executives' remunerations and performance of their respective organisations (Sharp, Mackay, Rankin \& Aling, 2012). The unions, investors and the media seize on any executive's remuneration that appears excessive, particularly if recent performance of the organisation is regarded as poor (Perry \& Zenner, 2001).

The academic researchers continue to focus on establishing the relationship between executives' remunerations and organisation performance. The remuneration of organisations' top executives should be virtually dependent on organisation performance and organisations that evaluate their CEOs will be successful overall even though the evaluation process is time consuming (Anderson \& Kleiner, 2003). The relation between executive remuneration, especially that of CEOs, and organisations' performance is still an important issue in financial debate (Traichal, Gallinger \& Johnson, 1999). According to Jensen and Murphy (1999), the executive remuneration literature has grown considerably over the last 50 years. Although the theoretical and empirical literature on executive compensation is fairly well developed, it is far from complete, according to Canarella and Gasparyan (2008).

The literature reviewed indicates that research on executive pay-performance, especially for CEOs, has yielded mixed and inconclusive results due to the principal-agent problem and managerial power approach. According to the agency framework, executive remuneration is an efficient means of aligning executive interests more closely with those of shareholders through a remuneration contract that rewards superior company performance (Jensen \& Meckling, 1976). The literature also indicates that innovation is needed to establish sound remuneration policies that are aligned with the longterm strategic plans of organisations. Corporate governance mechanisms are also utilised to ensure that the interests of both the principal and agent are aligned. According to McKnight and Weir (2009), corporate governance mechanisms are used to 'realign the interests of agents and principals and so reduce agency costs' (p. 140). The above discussions have identified two key points: firstly, executive remunerations should have a strong incentive effect and thus be related to performance and, secondly, due to potential conflicts of interest, safeguarding the objectivity of the remunerating process is crucial.

The corporate governance and disclosure requirements that are currently applicable in South Africa through the implementation of the Companies Act (2008) and King III (Institute of Directors Southern Africa, 2009) has given a clear indication that there is a need to ensure that executive remunerations are linked to their respective organisational performances. It is these regulatory changes and the current economic climate that make this research relevant. There is a need to link reward and performance, a powerful lever for driving business strategy.

\section{Research design Research approach}

This research study was an empirical exploratory quantitative study that was aimed at assessing the relationship between CEO total remuneration and the financial performance of an organisation as this approach was the best way to answer the research questions. The total remuneration consisted of FP (including benefits) and STIs (these incentives measure performance for up to 1 year and typically include profit share, commission and bonus schemes).

The research took the form of a desktop study and was archival in nature, using secondary sources to provide the organisation financials and their respective executive remuneration data for CEOs. The research approach was ex-post facto in nature in that the focus was on reporting the characteristics of the variables rather than playing any role in manipulating them (Saunders \& Lewis, 2012).

The research was also longitudinal in nature, allowing for the identification of trends and the isolation of any unusual observations either in the events or the data. 


\section{Research method}

\section{Research participants}

The research data utilised were obtained for publicly listed organisations on the Johannesburg Stock Exchange (JSE). According to the JSE listing requirements, listed organisations are contractually bound to adopt King III and the Companies Act of 2008 (Institute of Directors Southern Africa, 2009) and, as a result, these organisations were required to disclose the information needed for the research. The information used was deemed credible as it had been subject to financial audits that are stipulated by the JSE Securities Exchange rules.

The research data was drawn from the McGregor BFA database. McGregor BFA is South Africa's provider of financial data feeds and analysis tools and covers the JSE and global share prices as well as organisation information including annual reports and financial statements.

The research utilised publicly listed organisations on the JSE for the time period 2006-2012. The combined number of organisations listed on the JSE is 472 (JSE, 2009). The JSE top 40 organisations have a combined market capitalisation (MC) of $83.69 \%$ of the total JSE MC of all the 472 organisations on the JSE as of 25 April 2013 (Satrix, 2013). As a result, these JSE top 40 organisations were chosen as the research population as they represent a significant quantity of the total JSE. The proportion of the total capitalisation of the JSE top 40 organisations was seen as being large enough to be sufficient for the research. The same scoping process is consistent with that of previous research on executive remuneration done by Miller (1995).

The list of organisations on the JSE top 40 changes from year to year as a result of some organisations being replaced by organisations with growing MC effectively moving 'up the list'. The resulting number of organisations on the JSE top 40 between 2006 and 2012 was 57 in total. These 57 organisations were subjected to the following criteria for inclusion in the sample:

- The organisation had to have been on the JSE top 40 for the entire research period (2006-2012); this reduced the number of organisations to 27.

- The secondary research data required for the current research had to be available either from the McGregor BFA database or financial statements of the respective organisation; this reduced the number of organisations to 22.

- More than one organisation with the same executive receiving the same remuneration was considered as one organisation and the different organisation performance measures were added; this reduced the number of organisations to 21 .

Table 1 contains the list of organisations included in the research sample.

\section{Measuring instruments}

Total remuneration was defined to include $\mathrm{FP}$, the combination of the basic salary and benefits (car benefit,
TABLE 1: List of organisations included in the research sample.

\begin{tabular}{lll}
\hline Number & Organisation & Industry \\
\hline 1 & ABSA Group Ltd & Financials \\
2 & Anglo American Platinum Ltd & Basic materials \\
3 & Anglo American PLC & Basic materials \\
4 & BHP Billiton PLC & Basic materials \\
5 & Exxaro Resources Ltd & Basic materials \\
6 & FirstRand Ltd & Financials \\
7 & Impala Platinum Holdings Ltd & Basic materials \\
8 & Intu Properties PLC & Financials \\
9 & Investec PLC & Financials \\
10 & Kumba Iron Ore Ltd & Basic materials \\
11 & MTN Group Ltd & Telecommunications \\
12 & Naspers Ltd & Consumer Services \\
13 & Nedbank Group Ltd & Financials \\
14 & Old Mutual PLC & Financials \\
15 & Remgro Ltd & Industrials \\
16 & RMB Holdings Ltd & Financials \\
17 & SABMiller PLC & Consumer goods \\
18 & Sanlam Ltd & Financials \\
19 & Sasol Ltd & Oil and gas \\
20 & Standard Bank Group Ltd & Financials \\
21 & Tiger Brands Ltd & Consumer goods \\
\hline Note: listed alphabetically. &
\end{tabular}

other benefits and cost of employee benefits) received during the organisation's financial year, and STIs (these incentives measure performance for up to 1 year, and typically include profit share, commission and bonus schemes) (21st Century Pay Solutions, 2010). Executive remuneration figures that were either in Great British Pound (GBP), United States Dollar (USD) or Euro (EUR), and not in South African Rand (ZAR), were converted to ZAR utilising the average exchange rates between 2006 and 2012: GBP/ZAR exchange rate used was 13.08, USD/ZAR was 7.74 and EUR/ZAR was 10.47 .

Ideally, long-term incentives (LTIs) should be included in studies with the objective of determining the relationship between CEO remuneration and the financial performance of an organisation (Lippert \& Porter, 1997; Murphy, 1985). However, the measurement of LTIs has been proven problematic, uncertain and only based on future performance targets at the time total remuneration is awarded. It has therefore become accepted practice to include only FP and STIs in pay-performance analyses (Core, Holthausen \& Larcker, 1999).

The second unit of analysis was the financial performance of the organisations. For the purposes of this research, and largely based on past research work on pay-performance sensitivity, the following organisation financial performance measures were chosen (their definitions are sourced from McGregor BFA and Ward \& Price, 2006):

- Market capitalisation (MC): The total value of the issued shares of a publicly traded organisation. This figure is used to determine an organisation's size. The unit of measurements for MC is usually the currency of the country, in this case ZAR:

Market capitalisation $=$ Issued Shares $\times$ Market Price

[Eqn 1] 
- Earnings per share (EPS): The portion of an organisation's profit allocated to each outstanding share of common stock; it serves as an indicator of an organisation's profitability. The unit of measurements for EPS was South African Cents:

EPS $=\frac{\text { Net Income }- \text { Dividends On Preferred Stock }}{\text { Average Outstanding Shares }}$ [Eqn 2]

- Return on Equity (ROE): The amount of net income returned as a percentage of shareholders equity. It is a ratio that measures an organisation's efficiency in generating profit for each unit of shareholders' equity. ROE measures an organisation's profitability by revealing how much profit an organisation generates with the money shareholders have invested. The unit of measurements for ROE was a percentage:

$$
\mathrm{ROE}=\frac{\text { Net Income }}{\text { Shareholder Equity }}
$$

- Economic value added (EVA): A measure of an organisation's financial performance based on the residual wealth calculated by deducting cost of capital from its operating profit (adjusted for taxes on a cash basis). The unit of measurements for EVA was ZAR:

$$
\text { EVA }=\frac{\frac{\text { Net Operating Profit After Tax (NOPAT) }}{\text { Capital Employed (CE) }}}{\text { Weighted Average Cost of Capital (WACC) }} \text { [Eqn 4] }
$$

- Market value added (MVA): It was found that it is essential to analyse MVA by placing all organisations on a uniform basis. There are different approaches to establish this and the one chosen for this research was to express the MVA performance indicator as a ratio as opposed to the difference based on the general definition for MVA. The approach effectively standardises all the enterprises to have the same size and further facilitates comparisons between large and small organisations. However, the use of a ratio eliminates the contribution of size to value creation:

$$
\text { MVA }=\frac{\text { Market Value }}{\text { Total Capital }}
$$

\section{Research procedure}

The relationship between CEO remuneration and measures of organisation performance were observed over a period of 7 years between 2006 and 2012. The time period included the recessionary decline phase due to the 2008 global financial crisis and the August 2011 stock market fall (Jensen \& Murphy, 1999). The approach was chosen to ensure the validity of the research and also to ensure that the history for a given organisation would yield a maximum of seven observations. The 7-year period was also deemed sufficient to ensure limited influence of short-term irregularities, whilst being short enough to provide reliable estimates of the research constructs.

\section{Statistical analysis}

Correlation analysis and multiple regression analysis were used to determine two measures of the strength of the pay-performance relationship, namely the coefficient of correlation and the coefficient of determination respectively.

\section{Results \\ Descriptive statistics CEO remuneration: Fixed and variable pay}

Table 2 contains a summary of the descriptive statistics for FP received by CEOs between 2006 and 2012 .

Figure 1 shows a graphical representation of the descriptive statistics for CEO FP. Although the general trajectory of the average FP shows an upward trend, this increase slowed down during the recession period between 2008 and 2009. The FP mean and median plots in Figure 1 can both be approximated by linear equations with the coefficient of determination $\left(R^{2}\right)$ equal to $0.9212(p=0.0006100<0.10$ and $R=0.9598)$ and 0.9548 $(p=0.0001498<0.10$ and $R=0.9771)$, respectively.

Table 3 contains a summary of the descriptive statistics for STIs received by CEOs between 2006 and 2012.

Figure 2 shows a graphical representation of the descriptive statistics for CEO STIs. There was no general trajectory observed for the average (mean) STIs between 2006 and 2012. On the contrary, it was observed that the median STIs had a downwards moving trajectory which was approximated by a linear equation with the coefficient of determination $\left(R^{2}\right)$ equal to 0.6491 ( $p=0.02872<0.10$ and $\left.R=0.8056\right)$. For a linear approximation of the STI mean, the coefficient of determination was found to be equal to 0.02797 ( $p=0.7200>$ 0.1 , indicating statistical insignificance as the null hypothesis, which states that the slope of the linear approximation is equal to zero and has no effect, could not be rejected and $R=0.1672$ ). For an approximation equation with the coefficient of determination $\left(R^{2}\right)$ greater than that found for the median $\left(R^{2}=0.6491\right)$, the STI mean approximation equation was found to be of the fourth degree with the coefficient of determination $\left(R^{2}\right)$ being 0.9972 .

\section{Organisation performance measures}

Figure 3 shows the MC of the research sample, the combined JSE MC and the research sample percentage portion of the JSE between 2006 and 2012.

TABLE 2: CEO fixed pay summary ( $\left.\mathrm{R}^{\prime} 000\right)$.

\begin{tabular}{llllll}
\hline Year & Mean & Standard deviation & Minimum & Median & Maximum \\
\hline 2006 & 6655 & 4759 & 2153 & 5118 & 18612 \\
2007 & 7861 & 6265 & 2353 & 5774 & 25694 \\
2008 & 8102 & 5800 & 2211 & 6153 & 21392 \\
2009 & 7996 & 5107 & 2433 & 6368 & 21701 \\
2010 & 8821 & 5752 & 2637 & 6558 & 22104 \\
2011 & 9095 & 5662 & 2957 & 6913 & 23590 \\
2012 & 9814 & 6244 & 1359 & 7698 & 24697 \\
\hline$n=21$. & & & & &
\end{tabular}




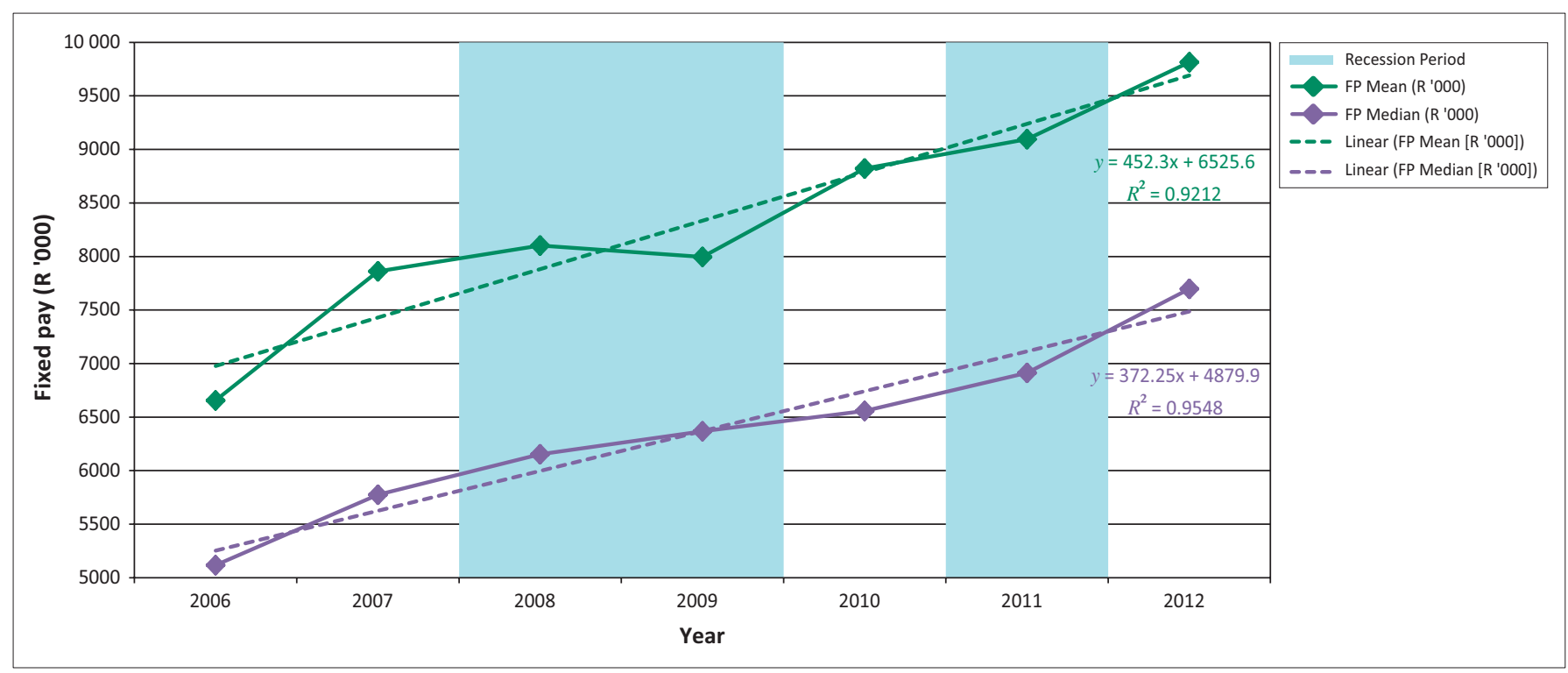

$n=21$.

FP, fixed pay.

FIGURE 1: Graphical representation of the descriptive statistics for CEO fixed pay.

TABLE 3: CEO short-term incentives summary ( $\left.R^{\prime} 000\right)$.

\begin{tabular}{lllll}
\hline Year & Mean & Standard deviation & Minimum & Median \\
\hline 2006 & 8381 & 7906 & 0 & 6500 \\
2007 & 10182 & 9399 & 0 & 8498 \\
2008 & 7473 & 8982 & 0 & 31797 \\
2009 & 6527 & 5821 & 0 & 39881 \\
2010 & 8160 & 8087 & 0 & 4770 \\
2011 & 10357 & 12470 & 0 & 4583 \\
2012 & 6953 & 7324 & 0 & 4918 \\
\hline
\end{tabular}

$n=21$

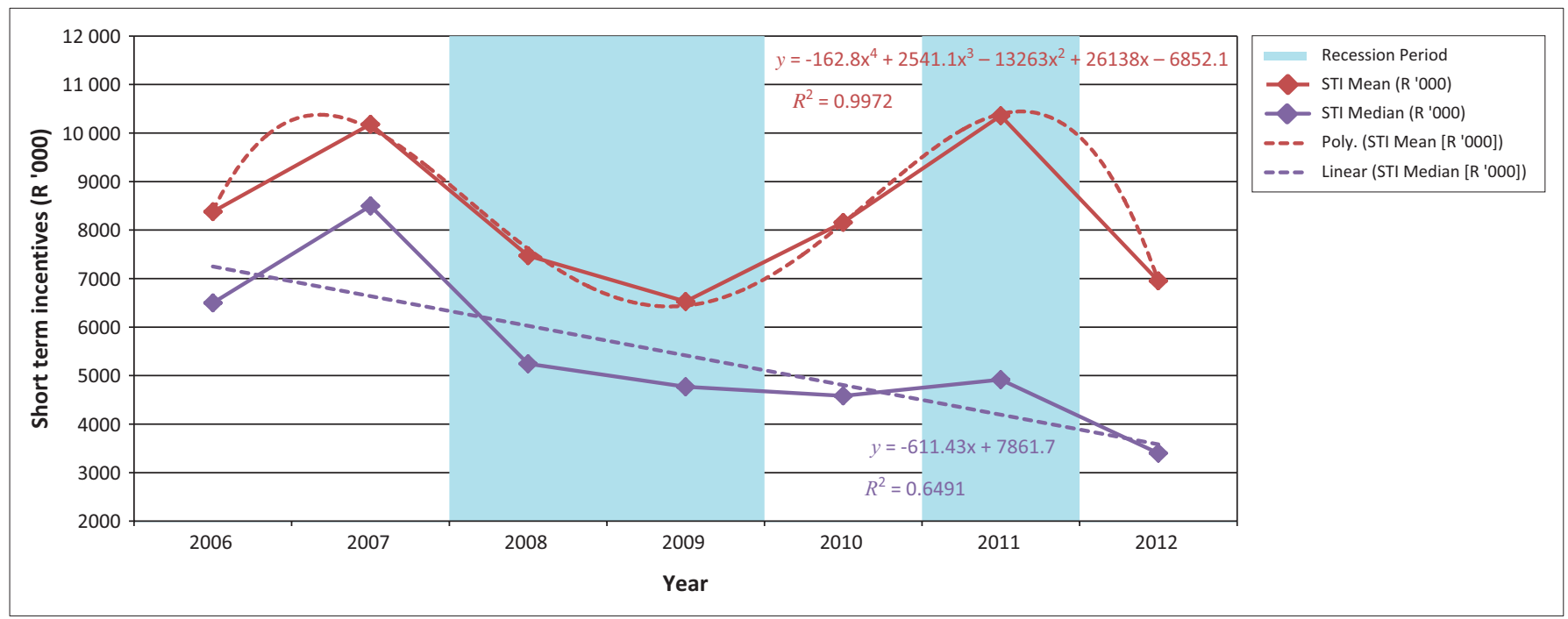

$n=21$.

STI, short-term incentives.

FIGURE 2: Graphical representation of the descriptive statistics for CEO short-term incentives.

Despite the fact that only the 21 organisations of the JSE top 40 have been included in the research sample, these organisations, as illustrated in Figure 3, had a combined MC of between 50\% and $82 \%$ of the total JSE MC for the research period between 2006 and 2012. The average percentage MC representation of the research sample to the JSE MC for the research period was $68 \%$.
Table 4 contains a summary of the means of the descriptive statistics for organisation performance measures selected for the research study: MC, EPS, ROE, EVA and MVA.

Table 5 contains a summary of the standard deviations for the organisation performance measures. 


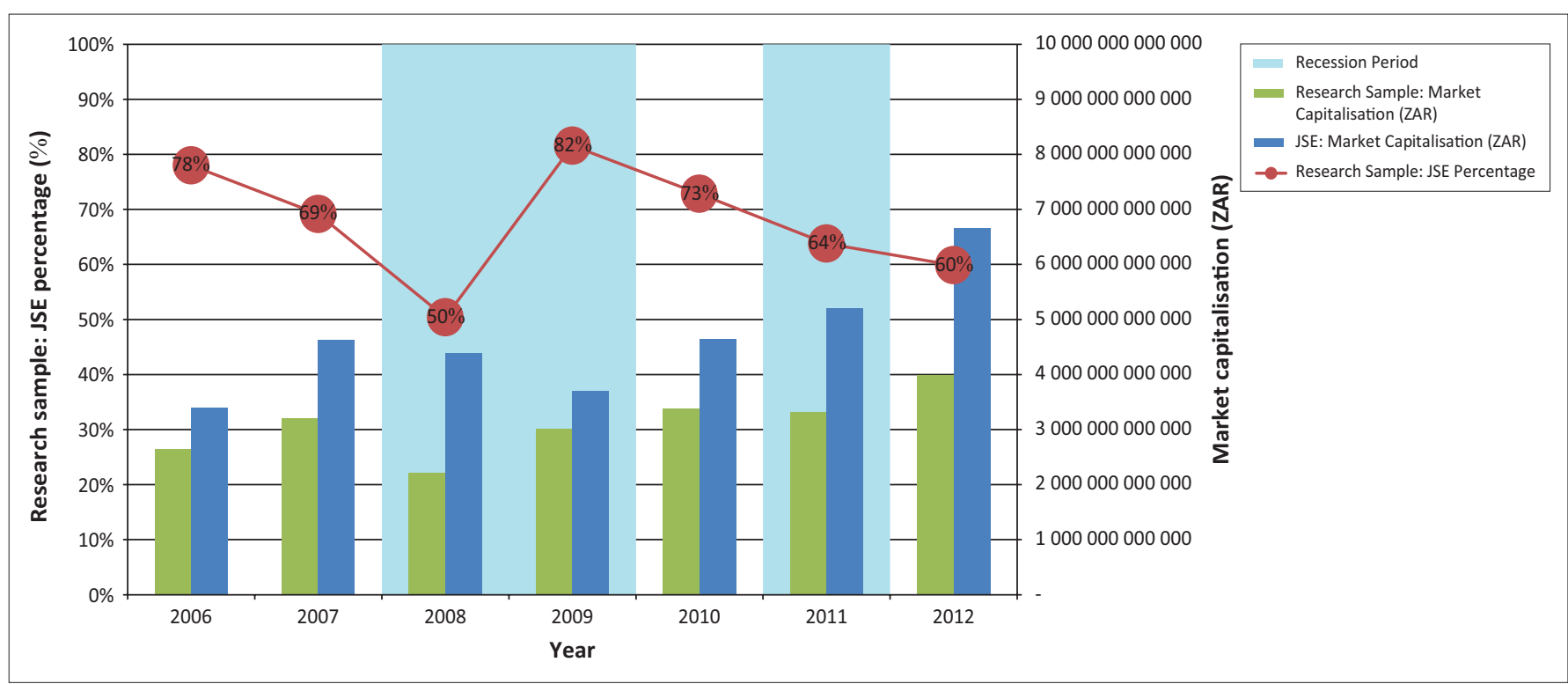

FIGURE 3: Market capitalisation: Research sample versus JSE.

TABLE 4: Organisational performance measures means.

\begin{tabular}{|c|c|c|c|c|c|}
\hline Year & Market capitalisation (ZAR) & Earnings per share (c) & Return on investment (\%) & Economic value added ( $\left.\mathrm{R}^{\prime} 000\right)$ & Market value added \\
\hline 2006 & 126127302078 & 411872 & 45.41 & -96040059 & 2.68 \\
\hline 2007 & 152428562410 & 372635 & 27.22 & -55045568 & 2.92 \\
\hline 2008 & 105504699867 & 408180 & 20.07 & 8437130 & 1.92 \\
\hline 2009 & 143840910288 & 277988 & 21.37 & -74430824 & 1.99 \\
\hline 2010 & 161080579054 & 351671 & 19.95 & -49226725 & 2.07 \\
\hline 2011 & 158206364568 & 436858 & 23.08 & 4623051 & 1.98 \\
\hline 2012 & 189816637829 & 257915 & 16.91 & -50811025 & 2.03 \\
\hline
\end{tabular}

TABLE 5: Organisational performance measures standard deviations.

\begin{tabular}{|c|c|c|c|c|c|}
\hline Year & Market capitalisation (ZAR) & Earnings per share (c) & Return on investment (\%) & Economic value added $\left(R^{\prime} 000\right)$ & Market value added \\
\hline 2006 & 117876561428 & 918429 & 56.88 & 486081146 & 2.00 \\
\hline 2007 & 147782173297 & 871015 & 23.38 & 360619615 & 2.90 \\
\hline 2008 & 101376853276 & 929707 & 39.34 & 214398037 & 1.11 \\
\hline 2009 & 138000304554 & 648033 & 30.31 & 338667551 & 1.60 \\
\hline 2010 & 151136297119 & 915648 & 19.79 & 383469055 & 1.34 \\
\hline 2011 & 141199051489 & 1155145 & 22.68 & 228620487 & 1.37 \\
\hline 2012 & 173261507601 & 552202 & 17.97 & 427188317 & 1.53 \\
\hline
\end{tabular}

$n=21$

\section{Results of the effects of the 2008 financial crisis}

The primary objective of this research was to determine the relationship between CEO remuneration and the financial performance of an organisation. As a result, the first research question investigated whether any structural changes occurred with regard to the mix of remuneration components CEOs received after the 2008 financial crisis. Figure 4 shows yearon-year percentage changes in CEO total remuneration (FP and STI) between 2006 and 2012. Also included in Figure 4 are the respective initial FP and STI averages (i.e. for ZAR-based figures; non-ZAR-based figures and the total research sample) for 2006.

Figure 4 shows that the percentage year-on-year change trajectories for CEO FP listed in ZAR and other currencies were observed to be similar, except in 2012 when the two were going in opposite directions. As for CEO STIs, the trajectories were observed to be similar except for 2011, when the CEO STIs listed in ZAR spiked whilst those listed in other currencies slowed down.

Figure 5 shows the calculated STI:FP ratios for means and medians between 2006 and 2012 with their respective trend lines. The trend lines indicate that there was a change in the mix in FP and STIs and that the change was statistically significant: $R^{2}$ mean $=0.4534(p=0.09732<0.10$ and $R=0.6733)$ and $R^{2}$ median $=0.7876(p=0.007677<0.10$ and $R=0.8874)$.

Figure 6 shows the mean percentage mix between FP and STI as a percentage of total remuneration received by CEOs. It is evident that FP increased from $44 \%$ in 2006 to $59 \%$ in 2012 and, in conjunction with Figure 4, indicates a trend of increasing FP compared to decreasing STIs. 


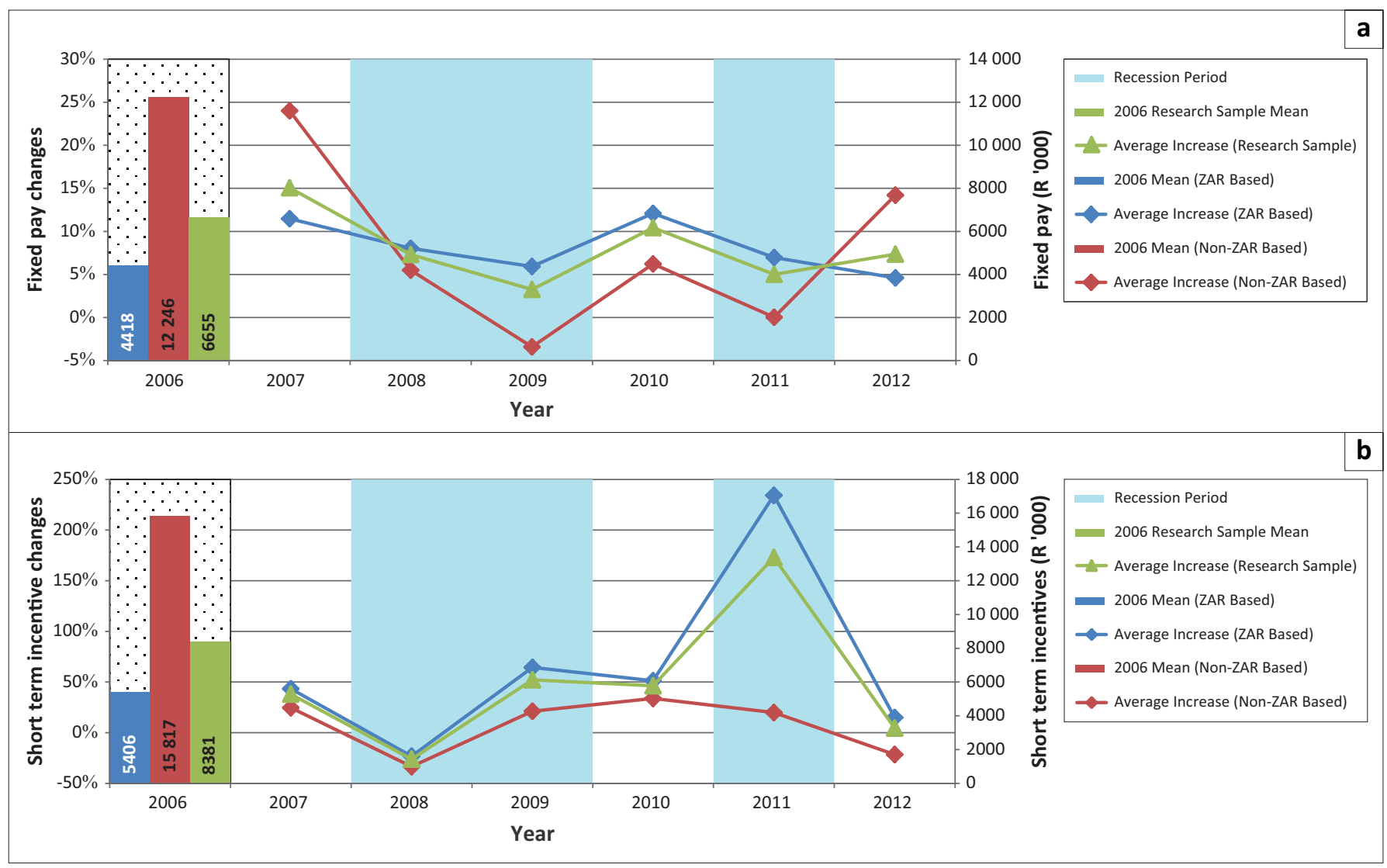

$n=21$.

FIGURE 4: CEO fixed pay (a) and short-term incentive (b) means and percentage changes.

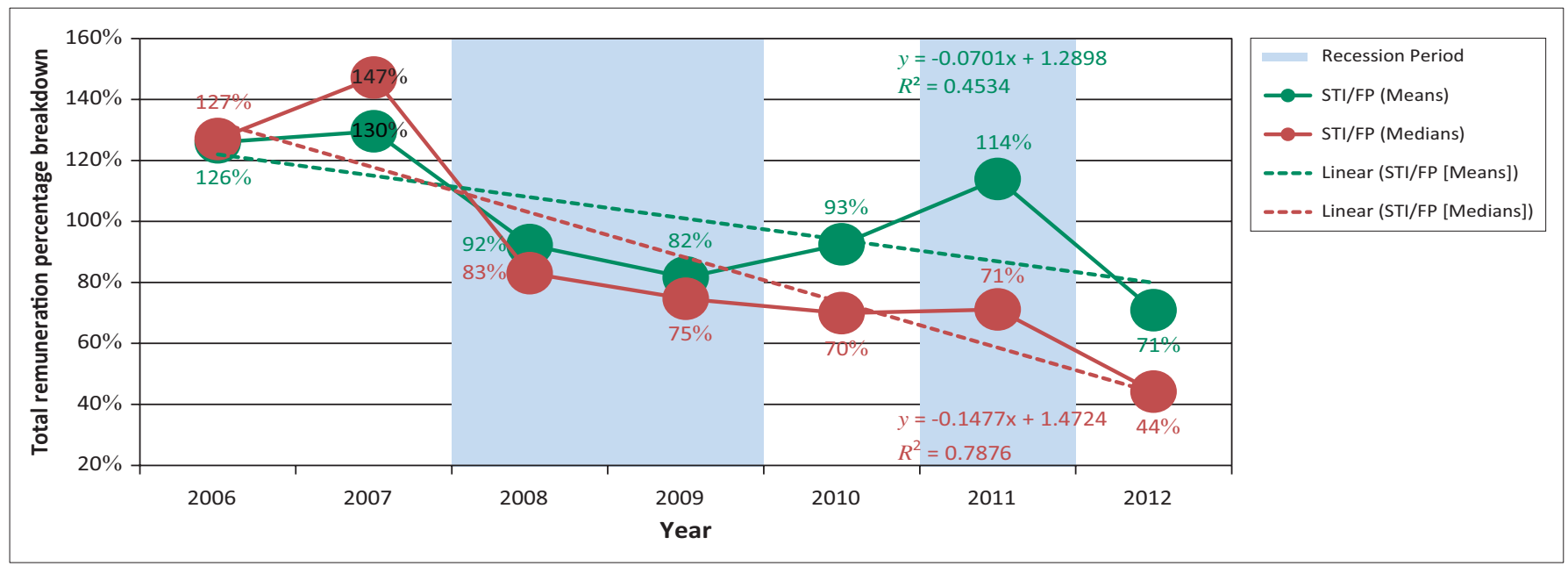

$n=21$.

$\mathrm{STI}$, short-term incentives; $\mathrm{FP}$, fixed pay.

FIGURE 5: Short-term incentive/fixed pay ratios (2006-2012).

\section{Results of the correlation between CEO remuneration and organisation performance}

Figure 7 shows the coefficient of correlation $(R)$ results for the correlation analysis that was done with FP as a dependant variable; independent variables considered for the correlation analysis included all the organisational financial performance measures selected for the research and are as listed on the horizontal axis of Figure 7 . Figure 7 also includes the 7 years' correlation results averages for each of the organisation financial performance measures and a table with all the correlation coefficient $(R)$ numerical values. For example, the correlation coefficient between FP (dependent variable) and MC (independent variable) in 2006 on Figure 7 was found to be 0.7709 , whilst that between FP (dependent variable) and MVA (independent variable) in 2006 on Figure 7 was -0.2619. Table 6 contains similar coefficient of correlation $(R)$ results 


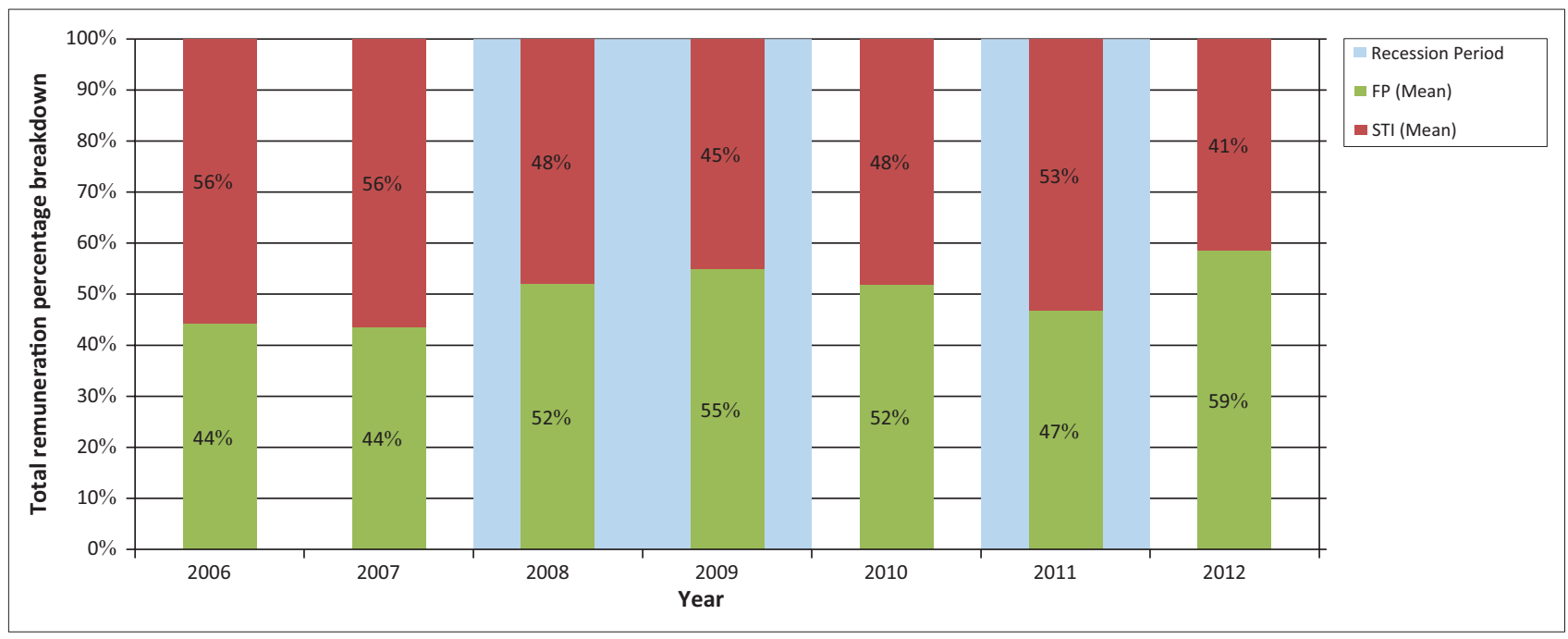

$n=21$.

FP, fixed pay; STI, short-term incentives.

FIGURE 6: Fixed pay - short term incentive mix (2006-2012).

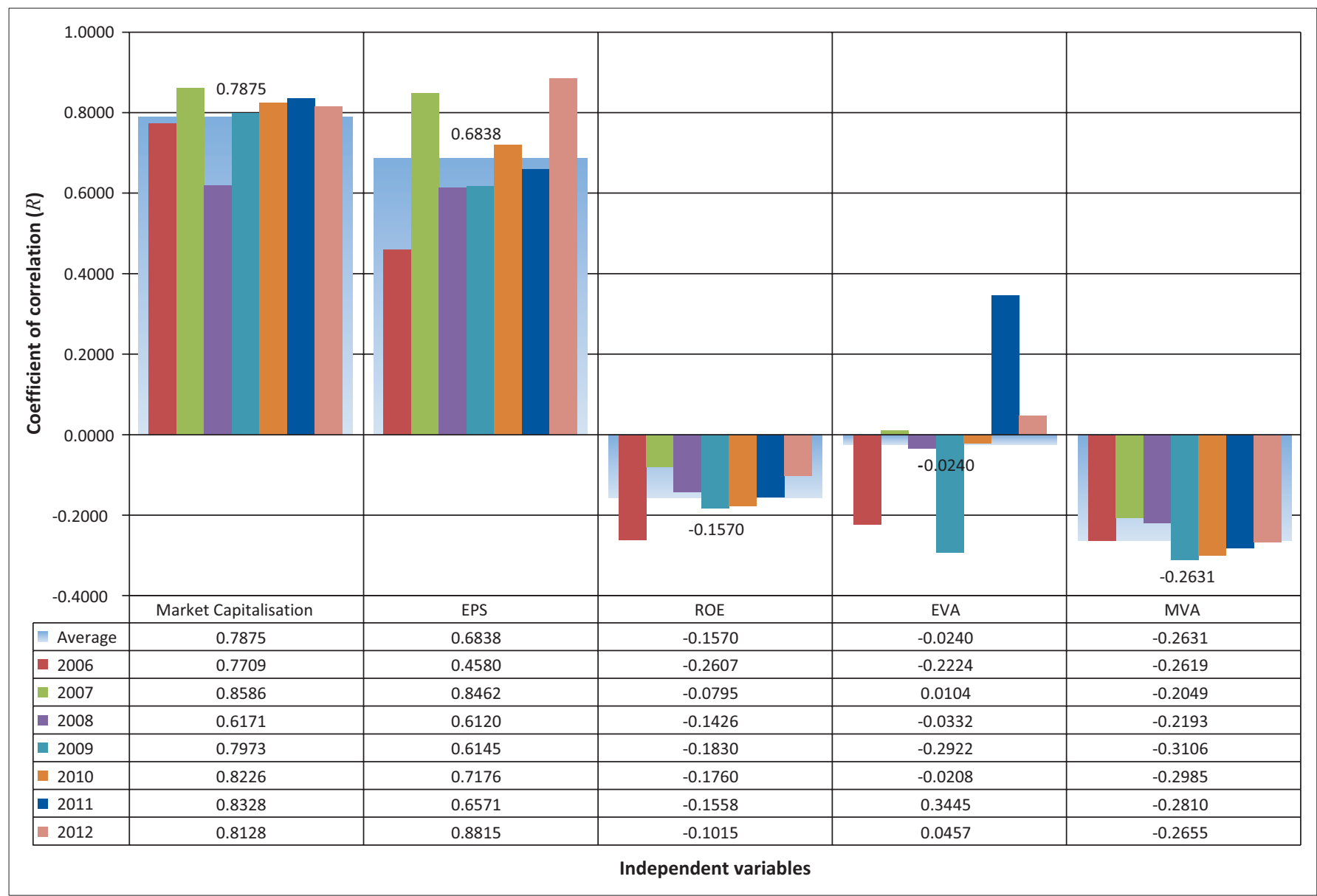

$n=21$.

EPS, Earnings per share; ROE, Return on Equity; EVA, economic value added; MVA, market value added.

FIGURE 7: Correlation analysis: Fixed pay and organisational performance measures.

to those found in Figure 7 and their associated $p$-values as determined using the Pearson product moment correlation coefficient method.

Figure 8 shows the correlation coefficient results for the correlation analysis that was done with STI means as the dependant variable; independent variables are as listed on the horizontal axis and include all the selected organisation financial performance measures. Figure 8 also includes the 7 years' correlation results averages. Table 7 contains similar coefficient of correlation $(R)$ results to those found in Figure 8 and their associated $p$-values as determined 
TABLE 6: Correlation analysis: Fixed pay and organisational performance measures.

\begin{tabular}{|c|c|c|c|c|c|c|c|c|c|c|}
\hline \multirow[t]{2}{*}{ Year } & \multicolumn{2}{|c|}{ Market capitalisation } & \multicolumn{2}{|c|}{ Earnings per share } & \multicolumn{2}{|c|}{ Return on investment } & \multicolumn{2}{|c|}{ Economic value added } & \multicolumn{2}{|c|}{ Market value added } \\
\hline & ZAR & $p$-value & ZAR & $p$-value & ZAR & $p$-value & ZAR & $p$-value & ZAR & $p$-value \\
\hline 2006 & 0.7709 & 4.310E-05 & 0.4580 & 0.0368 & -0.2607 & 0.2538 & -0.2224 & 0.3325 & -0.2619 & 0.2514 \\
\hline 2007 & 0.8586 & $6.336 \mathrm{E}-07$ & 0.8462 & 0.0000 & -0.0795 & 0.7319 & 0.0104 & 0.9644 & -0.2049 & 0.3729 \\
\hline 2008 & 0.6171 & $2.883 \mathrm{E}-03$ & 0.6120 & 0.0032 & -0.1426 & 0.5374 & -0.0332 & 0.8863 & -0.2193 & 0.3396 \\
\hline 2009 & 0.7973 & $1.507 \mathrm{E}-05$ & 0.6145 & 0.0030 & -0.1830 & 0.4271 & -0.2922 & 0.1987 & -0.3106 & 0.1706 \\
\hline 2010 & 0.8226 & $4.721 \mathrm{E}-06$ & 0.7176 & 0.0002 & -0.1760 & 0.4454 & -0.0208 & 0.9286 & -0.2985 & 0.1887 \\
\hline 2011 & 0.8328 & $2.804 \mathrm{E}-06$ & 0.6571 & 0.0012 & -0.1558 & 0.5002 & 0.3445 & 0.1262 & -0.2810 & 0.2172 \\
\hline 2012 & 0.8128 & 7.534E-06 & 0.8815 & 0.0000 & -0.1015 & 0.6616 & 0.0457 & 0.8439 & -0.2655 & 0.2448 \\
\hline
\end{tabular}

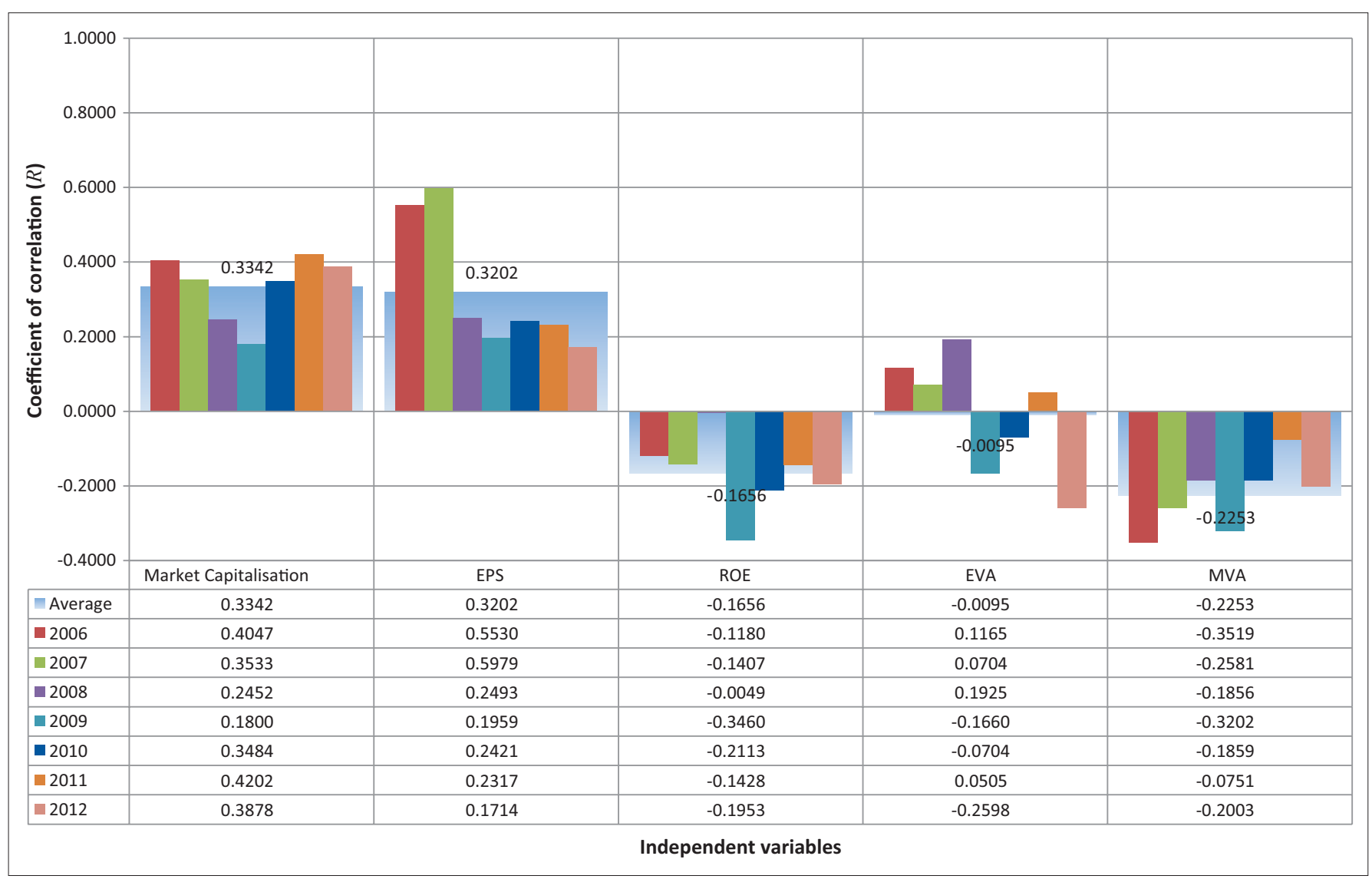

$n=21$.

EPS, Earnings per share; ROE, Return on Equity; EVA, economic value added; MVA, market value added.

FIGURE 8: Correlation analysis: Short-term incentives and organisational performance measures.

using the Pearson product moment correlation coefficient method.

Due to the extreme relative nature of outliers, especially for STIs paid to CEOs by organisations, the medians for CEOs remuneration were also considered in the correlation analysis. Medians are not influenced by outliers compared to means and in most cases when data sets have outliers, reporting the median as the central tendency of the data often gives a better 'typical' data value than the mean (Anderson, Sweeney, Williams, Freeman \& Shoesmith, 2007; Weiers, 2010).

Figure 9 shows the correlation results when the means and medians of the CEO remuneration and organisation performance measures were considered, with the FP and STIs as the two separately considered dependent variables.

Figure 10 shows the correlation coefficients absolute value differences in the results found in Figure 9 between the means and medians of the two dependent variables (i.e. FP or STI).

Figure 10 illustrates that the observed absolute value differences in the coefficients of correlation between FP means and FP medians when used as the dependent variable are between 0.01 and 0.29 . In contrast, the observed absolute differences in the correlation coefficient between STI means and medians when used as the dependent variable are between 0.25 and 0.60 . This illustrates that the absolute 
TABLE 7: Correlation analysis: Fixed pay and short-term incentives.

\begin{tabular}{|c|c|c|c|c|c|c|c|c|c|c|}
\hline \multirow[t]{2}{*}{ Year } & \multicolumn{2}{|c|}{ Market capitalisation } & \multicolumn{2}{|c|}{ Earnings per share } & \multicolumn{2}{|c|}{ Return on investment } & \multicolumn{2}{|c|}{ Economic value added } & \multicolumn{2}{|c|}{ Market value added } \\
\hline & ZAR & $p$-value & ZAR & $p$-value & ZAR & $p$-value & ZAR & $p$-value & ZAR & $p$-value \\
\hline 2006 & 0.4047 & 0.0688 & 0.5530 & 0.0093 & -0.1180 & 0.6106 & 0.1165 & 0.6150 & -0.3519 & 0.1177 \\
\hline 2007 & 0.3533 & 0.1162 & 0.5979 & 0.0042 & -0.1407 & 0.5429 & 0.0704 & 0.7616 & -0.2581 & 0.2587 \\
\hline 2008 & 0.2452 & 0.2841 & 0.2493 & 0.2757 & -0.0049 & 0.9830 & 0.1925 & 0.4032 & -0.1856 & 0.4204 \\
\hline 2009 & 0.1800 & 0.4350 & 0.1959 & 0.3947 & -0.3460 & 0.1244 & -0.1660 & 0.4720 & -0.3202 & 0.1571 \\
\hline 2010 & 0.3484 & 0.1217 & 0.2421 & 0.2904 & -0.2113 & 0.3578 & -0.0704 & 0.7618 & -0.1859 & 0.4197 \\
\hline 2011 & 0.4202 & 0.0579 & 0.2317 & 0.3122 & -0.1428 & 0.5370 & 0.0505 & 0.8280 & -0.0751 & 0.7463 \\
\hline 2012 & 0.3878 & 0.0824 & 0.1714 & 0.4575 & -0.1953 & 0.3963 & -0.2598 & 0.2554 & -0.2003 & 0.3839 \\
\hline
\end{tabular}

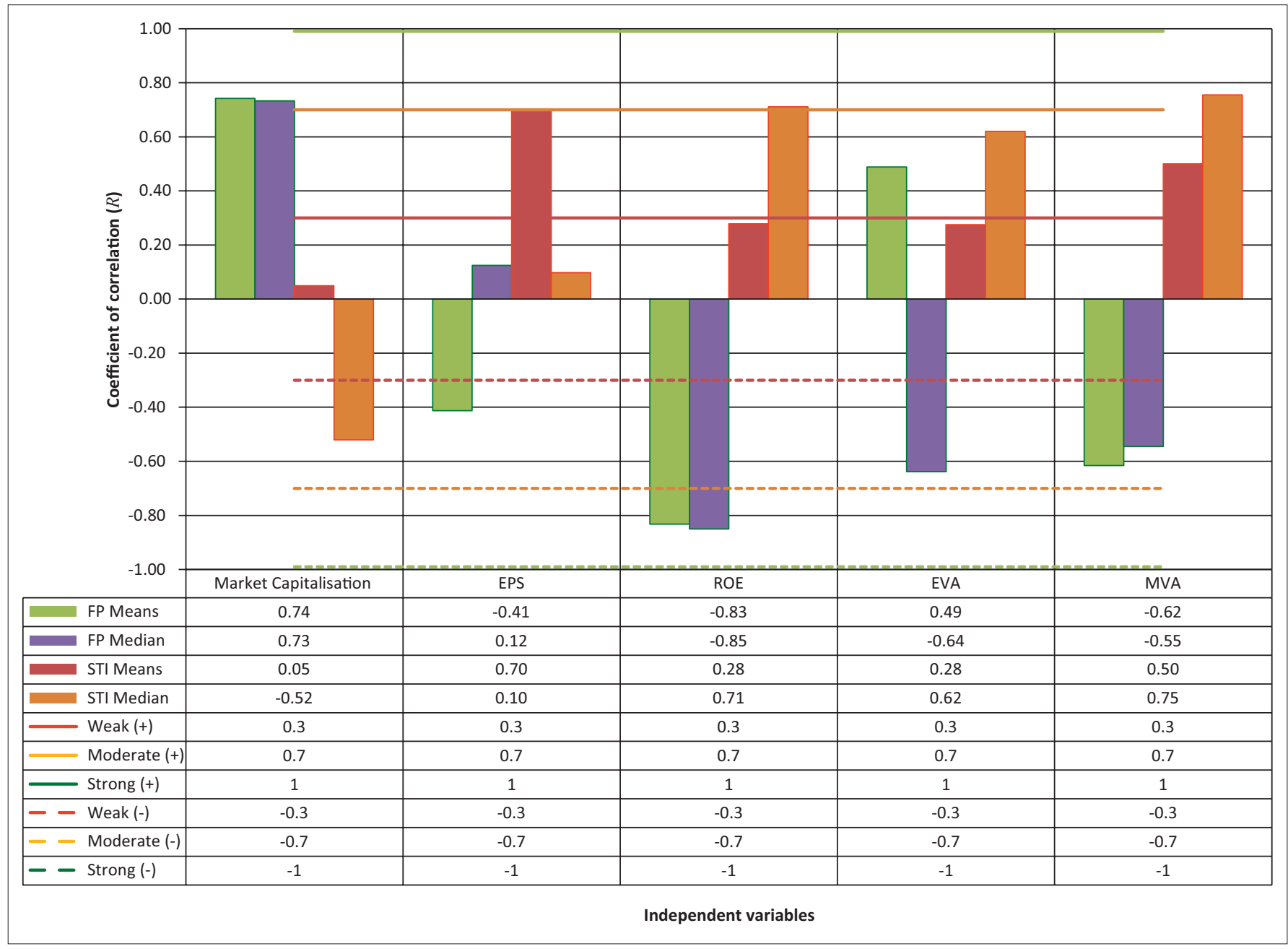

$n=21$.

EPS, Earnings per share; ROE, Return on Equity; EVA, economic value added; MVA, market value added.

FIGURE 9: Correlation coefficients results: Means and medians.

differences between means and medians are higher for STIs as compared to FP.

\section{Discussion}

The primary objective of this research study was to investigate the relationship between $\mathrm{CEO}$ remuneration and organisation performance in South Africa between 2006 and 2012 and to determine whether the two constructs were positively correlated. Understanding this relationship is critical to finding a suitable model to structure executive remuneration that will protect shareholders from over-remunerating executives in times of economic appreciation, whilst protecting executives from being underpaid in times of economic depreciation.

The first research question investigated was whether there were any structural changes to the total remuneration received by CEOs as a result of the global financial crisis. The implementation of the Companies Act (2008) and King III (2009) were expected to cause some form of structural changes in remuneration, more specifically, and in the context of the current research, to ensure that there is a link between executive remuneration and organisation performance. 


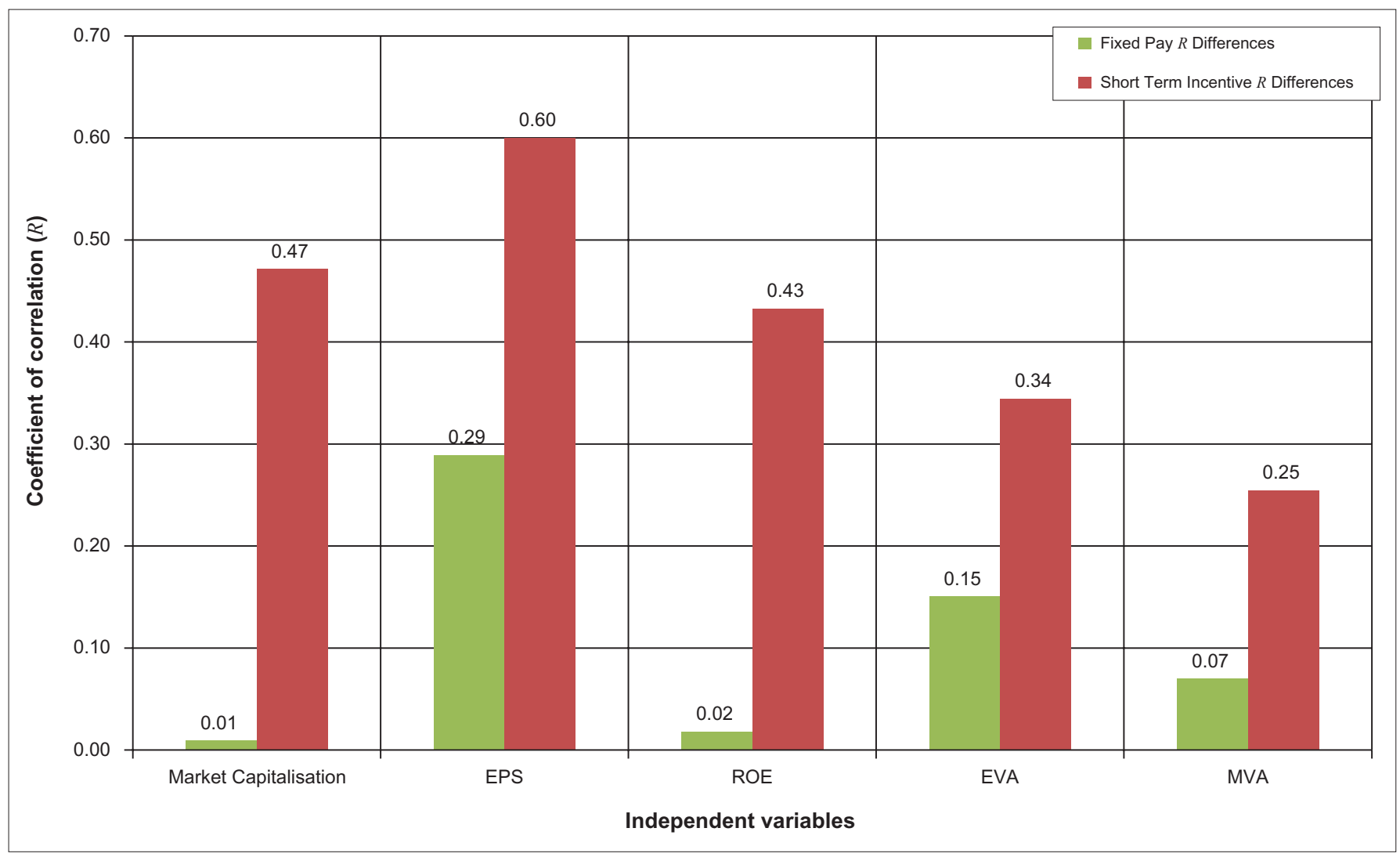

$n=21$.

EPS, Earnings per share; ROE, Return on Equity; EVA, economic value added; MVA, market value added.

FIGURE 10: Means and medians correlation coefficients $(R)$ differences.

The research findings strongly suggest that some structural changes to the total remuneration of CEOs occurred after 2008. The main structural change was an increase in FP accompanied by a decrease in STIs. These findings can be supported further by the calculated means and medians of the STI to FP ratios. The trend lines for the means and medians show that there was an upward movement between 2006 and 2007, which was followed by a downward movement in 2008. The general regression equations for the STI:FP ratios have the following negative slopes: $\beta_{\text {mean }}=-0.0701\left(R_{\text {mean }}^{2}=0.4534, p=0.09732<\right.$ $0.10)$ and $\beta_{\text {median }}=-0.1477\left(R_{\text {median }}^{2}=0.7876, p=0.007677<0.10\right)$.

It can be seen that CEOs are becoming more innovative as they are noticeably moving away from focusing on STIs, which are categorised as performance-related elements of remuneration. As a result, CEOs are focusing more on FP rather than STIs. This change in focus results in the Companies Act (2008) and King III (2009) requirements being less effective, as CEOs avoid being measured for performance. As Jensen and Murphy (1999, p. 64) state, 'the relentless focus on how much CEOs are remunerated diverts public attention from the real problem - how CEOs are paid'. Whilst the implementation of the Companies Act (2008) and King III (2009) was expected to cause structural changes driving the link between executive remuneration and organisation performance, the opposite has been observed.

The second research question was aimed at determining the correlation between CEO total remuneration and organisation performance. Corporate governance and economic theories of remuneration largely suggest that 'organisational performance should affect an executive's remuneration to the extent that it serves as a proxy for unobservable managerial effort or productivity' (Murphy, 1985, p. 20). The expected pay-performance relationship was that a direct and strong relationship would be found to exist between CEO remuneration and measures of organisational performance.

Results indicate that FP was found to be weakly and inversely correlated to ROE during the research study period between 2006 and $2012\left(R_{\text {average }}=-0.1570\right)$ (Bebchuk et al., 2010). The inverse relationship between FP and MVA was found to be weak to moderate $\left(R_{\text {average }}=-0.2631\right)$ (Bebchuk et al., 2010). The relationship between FP and EVA was found to be weak to moderate, and inverse in some years $\left(R_{2006}=-0.2224\right.$, $R_{2008}=-0.0332, R_{2009}=-0.2922$ and $\left.R_{2010}=-0.0208\right)$ whilst direct in other years $\left(R_{2007}=0.0104, R_{2011}=0.3445\right.$ and $\left.R_{2012}=0.0457\right)$. Both direct relationships between MC and EPS with FP were found to be moderate to strong $\left(R_{\text {MCaverage }}=0.7875\right.$ and $\left.R_{\text {EPSaverage }}=0.6838\right)$.

Results indicate that STIs had an inverse relationship with ROE and the strength of the relationship was weak to moderate $\left(R_{\text {average }}=-0.1656\right)$. A similar relationship, in terms of direction and strength, was observed between STIs and MVA and the relationship was inverse and weak to moderate $\left(R_{\text {average }}=0.2253\right)$. The relationship between STIs and EVA was found to be generally weak, and direct in some years 
$\left(R_{2006}=0.1165, R_{2007}=0.0704, R_{2008}=0.1925\right.$ and $\left.R_{2011}=0.0505\right)$ whilst inverse in other years $\left(R_{2009}=-0.1660, R_{2010}=-0.0704\right.$ and $\left.R_{2012}=-0.2598\right)$. Both direct relationships between MC and EPS with STIs were found to be weak to moderate $\left(R_{\text {MCaverage }}=0.3342\right.$ and $\left.R_{\text {EPSaverage }}=0.3202\right)$.

The most stable of the findings was the direct relationship of CEO total remuneration with MC and EPS; another was the inverse relationship with ROE and MVA.

The findings of the relationship between CEO total remuneration and ROE support those found by Van Blerck (2012) and, more importantly, the behaviour of the relationship during and immediately after financial crisis was similar to what Van Blerck found in 2007 in the South African financial services sector.

MVA represents value created whilst ROE measures an organisation's profitability by revealing how much profit an organisation generates with the money shareholders have invested. The inverse relationship found between these performance measures and CEO total remuneration is of major concern, especially as value creation occurs during global financial difficulties when executives adopt a riskaverse orientation.

The relationship between CEO total remuneration and EVA tended to change direction depending on the global economic standings. When the global economy was experiencing uncertainty or difficulties (e.g. 2008 global financial crisis and August 2011 stock market fall), EVA was found to be leaning towards being more directly related to CEO total remuneration. When the global economy was performing well, EVA was found to be leaning towards being more inversely related to $\mathrm{CEO}$ total remuneration as organisations earned more profits and allocated less to the cost of financing their respective organisations' capital.

The correlation findings with regard to EVA suggest that CEOs, during economic certainty, engage more in empire building, taking investment projects that may not be profitable for the shareholder, but are undertaken purely to increase the size of the organisation. Similar findings were made by Hope and Thomas (2008), who concluded that executives grow organisations due to the fact that boards have limited information on which to judge their ability, and so growth in organisation size seems to be the next best solution in ensuring that executives are viewed favourably.

The average FP had a direct relationship with MC and EVA over the 7-year research period and the relationships were found to be strong and moderate. Results also indicate that average FP was inversely correlated to EPS, ROE and MVA and the respective relationships were moderate, strong and moderate.

Except for EVA, the relationship between STIs and all organisation financial performance measures were directly opposite to those found for FP. STIs were found to be moderately inversely related to $\mathrm{MC}$ and directly related to the other four organisation financial performance measures. The relative relationship strengths of STIs with the EPS, ROE, EVA and MVA were found to be weak, strong, moderate and strong.

Shaw and Zhang (2010) point out that efficient remuneration contracts will link executive remuneration with organisation performance, whilst providing strong incentives for executives to operate in shareholders' best interests. The findings of this research, with regard to the directions and strengths of the relationships between CEO FP and organisation performance measures, suggest that the general pay-performance link has been lost. The directions and strengths of the relationships between STIs and organisation financial performance measures indicate that a link exists between what executives receive as STIs and accountingbased measures of performance.

The irony is that whilst the STI link with organisation financial performance measures (i.e. accounting-based measures) exists, the FP link with organisation performance measures continues to be eroded. Executives are avoiding STIs and paying greater attention to FP to reduce the impact of performance-related elements in determining their remuneration.

The above findings strongly suggest that failure to reward or punish executives for either superior or poor performance will continue to erode the link between CEO total remuneration and financial organisation performance. The optimal contracting approach does not appear to be working and the managerial power approach seems dominant, that is executive remuneration is not being used as a potential instrument for addressing agency problems, but has become part of the agency problem itself (Frydman \& Jenter, 2010).

The long-term impact of this, according to Jensen and Murphy (1999), Anderson and Kleiner (2003) and Haynes et al. (2007), will be entrenched bureaucratic remuneration systems in which boards become reluctant to either reward CEOs for superior performance or punish them for poor performance.

\section{Practical implications}

This research suggests that a stronger test of the payperformance link and the power of incentive design is required in order to ensure that executives are rewarded or punished for performance. The question on how executives are paid also needs to be considered. The research identifies the need for a robust and valid CEO pay-performance model to ensure consistency with the agency notion that top executives are rewarded for increases in shareholder wealth.

It is suggested that boards and remuneration committees need to pay more attention to the different performance measures available in assessing CEO performance. More attention should also be paid to reducing the subversive behaviour of CEOs, which serves to reduce the efficacy of the Companies Act (2008) and King III (2009) by avoiding the issue of CEOs being measured for performance. 


\section{Research limitations}

This research only investigated the specific relationship between performance and pay and did not include information on the causal factors influencing CEO remuneration and the financial performance of the organisations. In addition, the size of the organisations studied, and the possible effect that this would have on the total remuneration of the CEO, was deemed to be beyond the scope of this research. The fact that all the organisations selected were large organisations could address the problem of organisation size as a threat to the validity of the research; however, it is suggested that further research should be conducted to see if the same findings apply to small and medium organisations.

\section{Conclusion}

In theory, efficient remuneration contracts will be designed well enough to link executive remuneration with organisation performance and provide strong incentives for executives to operate organisations in the best interest of the shareholders. Additionally, the Companies Act (2008) and King III (2009) specify that there should be a positive correlation between executive remuneration and organisation performance. The primary objective of this research was to take advantage of the available information on CEO remuneration data and requirements in terms of positive correlation between $\mathrm{CEO}$ remuneration and financial performance of organisations.

Based on the findings of the current research, it can be concluded that there have been structural changes after the 2008 global financial crisis with regard to total remuneration received by CEOs; these structural changes were further amplified after the August 2011 stock market fall. The findings of the current research indicate that these changes were deliberate as CEO were focusing more on fixed pay and moving away from performancerelated short-term incentives, thus creating a disconnect between what CEOs are being paid and the performance of organisations.

More attention needs to be paid to the different behaviours of top executives, especially CEOs, in making the Companies Act (2008) and King III (2009) requirements ineffective as they avoid being measured on the performance of their organisations.

\section{Acknowledgements Competing interests}

The authors declare that they have no financial or personal relationships that may have inappropriately influenced them in writing this article.

\section{Authors' contributions}

M.B. (University of Johannesburg) was the project leader and academic supervisor and also contributed to writing the manuscript. M.F.M. (University of Pretoria) was responsible for project design, field work and writing up the research.

\section{References}

21st Century Pay Solutions. (2010). Global reward trends. Retrieved August 24 2013, from https://www.saica.co.za/Portals/0/about/Committees/Global Reward Trends.pdf

Abraham, R., Harris, J., \& Auerbach, J. (2014). CEO-Pa performance sensitivity. Technology and Investment, 5, 125-136. http://dx.doi.org/10.4236/ti.2014.53013

Amzaleg, Y., Azar, O.H., Ben-Zion, U., \& Rosenfield, A. (2014). CEO control, corporate performance and pay-performance sensitivity, Journal of Economic Behavior \& Organization, 106(C), 166-174. http://dx.doi.org/10.1016/j.jebo.2014.07.004

Anderson, B., \& Kleiner, B.H. (2003). How to evaluate the performance of chief executive officers effectively. Management Research News, 26(2/3/4), 3-11.

Anderson, D.R., Sweeney, D.J., Williams, T.A., Freeman, J., \& Shoesmith, E. (2007). Statistics for business and economics. (6th edn.). London, UK: Thomson Learning.

Attaway, M.C. (2000). A study of the relationship between company performance and CEO compensation. American Business Review, 18(1), 77-85.

Bacidore, J.M., Boquist, J.A., Milbourn, T.T., \& Thakor, A.V. (1997). The search for the best financial performance measure. Financial Analysts Journal, 53(3), 11-20. http://dx.doi.org/10.2469/faj.v53.n3.2081

Bebchuk, L.A., \& Fried, J.M. (2003). Executive compensation as an agency problem. Cambridge, MA: National Bureau of Economic Research. http://dx.doi. org/10.3386/w9813

Bebchuk, L.A., \& Fried, J.M. (2005). Pay without performance: Overview of the issues. Journal of Applied Corporate Finance, 17(4), 8-23. http://dx.doi.org/10.1111/ j.1745-6622.2005.00056.x

Bebchuk, L.A., Cohen, A., \& Holger, S. (2010). The wages of failure: Executive compensation at Bear Stearns and Lehman 2000-2008. Yale Journal on Regulation, 27(2), 257-282.

Bebchuk, L.A., Fried, J.M., \& Walker, D.I. (2002). Managerial power and rent extraction in the design of executive compensation. Cambridge, MA: National Bureau of Economic Research. http://dx.doi.org/10.3386/w9068

Bruce, A., Buck, T., \& Main, B.G. (2005). Top executive remuneration: A view from Europe. Journal of Management Studies, 42(7), 1493-1506. http://dx.doi. org/10.1111/j.1467-6486.2005.00553.x

Bussin, M. (2011). The remuneration handbook for Africa: A practical and informative handbook for managing and recognition in Africa. Randburg: Knowres Publishing.

Canarella, G., \& Gasparyan, A. (2008). New insights into executive compensation and firm performance: Evidence from a panel of 'new economy' firms 1996-2002. Managerial Finance, 34(8), 537-554. http://dx.doi.org/10.1108/ 03074350810874064

Carpenter, M.A., \& Sanders, W. (2002). Top management team compensation: The missing link between CEO pay and firm performance? Strategic Management Journal, 23(4), 367-375. http://dx.doi.org/10.1002/smj.228

Chari, L. (2009). Measuring value enhancement through economic value added: Evidence from literature. IUP Journal of Applied Finance, 15(9), 46-62.

Core, J.E., Holthausen, R.W., \& Larcker, D.F. (1999). Corporate governance, chief executive officer compensation, and firm performance. Journal of Financial Economics, 51(3), 371-406. http://dx.doi.org/10.1016/S0304-405X(98)00058-0

Doscher, T. \& Friedl, G. (2010). Corporate governance, stakeholder power and executive compensation. OR Spectrum, 33(2), 309-331. http://dx.doi.org/10.1007/s00291010-0218-z

Duffhues, P., \& Kabir, R. (2008). Is the pay-performance relationship always positive? Evidence from the Netherlands. Journal of Multinational Financial Management, 18(1), 45-60. http://dx.doi.org/10.1016/j.mulfin.2007.02.004

Edmans, A., \& Gabaix, X. (2009). Is CEO pay really inefficient? A survey of new optimal contracting theories. European Financial Management, 15(3), 486-496. http:// dx.doi.org/10.1111/j.1468-036X.2009.00500.x

Edmans, A., Gabaix, X., Sadzik, T., \& Sannikov, Y. (2012). Dynamic CEO compensation Journal of Finance, 67(5), 1603-1618. http://dx.doi.org/10.1111/j.1540 6261.2012.01768.

Ellig, B.R. (2007), The complete guide to executive compensation. New York, NY: McGraw-Hill.

Enrione, A., Mazza, C., \& Zerboni, F. (2006). Institutionalizing codes of governance. American Behavioral Scientist, 49(7), 961-973. http://dx.doi. org/10.1177/0002764205285175

Eriksson, T., \& Lausten, M. (2000). Managerial pay and firm performance. Scandinavian Journal of Management, 16(3), 269-286. http://dx.doi.org/10.1016/S09565221(99)00026-3

Fatemi, A., Desai, A.S., \& Katz, J.P. (2003). Wealth creation and managerial pay: MVA and EVA as determinants of executive compensation. Global Finance Journal, 14(2), 159-179. http://dx.doi.org/10.1016/S1044-0283(03)00010-3

Firth, M., Fung, P.M., \& Rui, O.M. (2006). Corporate performance and CEO compensation in China. Journal of Corporate Finance, 12(4), 693-714. http:// dx.doi.org/10.1016/j.jcorpfin.2005.03.002

Frydman, C., \& Jenter, D. (2010). CEO compensation. Annual Review of Financial Economics, 2, 75-102. http://dx.doi.org/10.1146/annurev-financial-120209-133958 
Harvey, C. (2012). Optimal contract. The Free Dictionary by Fairelex. Retrieved June 15 2013, from http://financial-dictionary.thefreedictionary.com/Optimal+Contract

Haynes, M., Thompson, S., \& Wright, M. (2007). Executive remuneration and corporate divestment: Motivating managers to make unpalatable decisions. Journal of Business Finance \& Accounting, 34(5-6), 792-818. http://dx.doi. org/10.1111/j.1468-5957.2007.02008.x

Hope, O.-K., \& Thomas, W.B. (2008). Managerial empire building and firm disclosure. Journal of Accounting Research, 46(3), 591-626. http://dx.doi.org/10.1111/ j.1475-679X.2008.00289.x

Institute of Directors Southern Africa. (2009). King III report on corporate governance for South Africa. Pietermaritzburg: Author.

Jensen, M., \& Meckling, W.H. (1976). Theory of the firm: Managerial behavior, agency costs and ownership structure. Journal of Financial Economics, 3(4), 305-360. http://dx.doi.org/10.1016/0304-405X(76)90026-X

Jensen, M., \& Murphy, K. (1999). CEO incentives: It's not how much you pay, but how. Harvard Business Review, 3, 64-76. http://dx.doi.org/10.2139/ssrn.146148

JSE. (2009). Global classification system. Retrieved April 02, 2013, from http://www. jse.co.za/Products/FTSE-JSE/Classification-System.aspx - Global

Kaplan, S.N. (2013). CEO pay and corporate governance in the US: Perceptions, facts and challenges. Journal of Applied Corpoaret Finance, 25(2), 2-19. http://dx.doi. org/10.1111/jacf.12013

Kyriazis, D., \& Anastassis, C. (2007). The validity of the economic value added approach: An empirical application. European Financial Management, 13(1) 71-100. http://dx.doi.org/10.1111/j.1468-036X.2006.00286.x

Laffont, J.-J., \& Martimort, D. (2002). The theory of incentives, The principal-agent model. Princeton, NJ: Princeton University Press.

Leon, P. (2012). Marikana, Mangaung and the South African mining industry. Webber Wentzel report. Cape Town: South African Institute of International Affairs.

Lin, D., \& Kuo, H. (2013). Chief executive compensation: An empirical study of fat cat CEOs. The International Journal of Business and Finance Research, 7 $27-42$.

Lindqvist, J., \& Grunditz, J. (2004). CEO compensation and company performance: An empirical study of the situation in Sweden's listed companies. Master's thesis, School of Business, Economics and Law, Goteborg University, Sweden.

Lippert, R.L., \& Porter, G. (1997). Understanding CEO pay: A test of two pay-toperformance sensitivity measures with alternative measures of alignment and influence. Journal of Business Research, 40(2), 127-138. http://dx.doi. org/10.1016/S0148-2963(96)00283-4

Mantshantsha, S. (2007, February). Is there a case for a maximum salary? USB Agenda Magazine. Retrieved from http://hdl.handle.net/10019.1/4653

Marais, J., \& Lefifi, T.A. (2013, April 28). Bang goes bank boss pay. Sunday Times, p. 1.

Matsumura, E.M., \& Shin, J.Y. (2005). Corporate governance reform and CEO compensation: Intended and unintended consequences. Journal of Business Ethics, 62(2), 101-113. http://dx.doi.org/10.1007/s10551-005-0175-7

McGregor BFA Database. (n.d.). Retrieved n.d., from http://www.inetbfa.com/tag/ mcgregor-bfa/

McKnight, P.J., \& Weir, C. (2009). Agency costs, corporate governance mechanisms and ownership structure in large UK publicly quoted companies: A panel data analysis. The Quarterly Review of Economics and Finance, 49(2), 139-158. http:// dx.doi.org/10.1016/j.qref.2007.09.008

Merhebi, R., Pattenden, K., Swan, P.L., \& Zhou, X. (2006). Australian chief executive officer remuneration: Pay and performance. Accounting \& Finance, 46(3), 481497. http://dx.doi.org/10.1111/j.1467-629X.2006.00178.x

Miller, D.J. (1995). CEO salary increase may be rational after all: Referents and contracts in CEO pay. Academy of Management Journal, 38(5), 1361-1385. http:// dx.doi.org/10.2307/256861
Morrissey, J. (2009, September 23). More angry investors say, throw the boards out. Time Business \& Money. Retrieved April 06, 2013, from http://www.time.com/ time/business/article/0,8599,1925344,00.html

Mueller, D.C. (2006). Corporate governance and economic performance. International Review of Applied Economics, 20(5), 623-643. http://dx.doi.org/10.1080/ 02692170601005598

Murphy, K.J. (1985). Corporate performance and managerial remuneration: An empirical analysis. Journal of Accounting and Economics, 7(1), 11-42. http:// dx.doi.org/10.1016/0165-4101(85)90026-6

O’Byrne, \& Gressle, M. (2013). How 'competitive pay' undermines pay for performance (and what companies can do to avoid that). Journal of Applied Corporate Finance, 25(2), 26-38. http://dx.doi.org/10.1111/jacf.12014

O'Reilly, C.A., \& Main, B.G. (2010), Economic and psychological perspectives on CEO compensation: A review and synthesis, Industrial and Corporate Change, 19(3), 675-712. http://dx.doi.org/10.1093/icc/dtp050

Ozkan, N. (2011). CEO compensation and firm performance: An empirical investigation of UK panel data. European Financial Management, 17(2), 260-285. http://dx.doi. org/10.1111/j.1468-036X.2009.00511.x

Perry, T., \& Zenner, M. (2001). Pay for performance? Government regulation and the structure of compensation contracts. Journal of Financial Economics, 62(3), 453488. http://dx.doi.org/10.1016/S0304-405X(01)00083-6

Republic of South Africa. (2008). Companies Act, Act No. 71 of 2008. South Africa: Department of Justice.

Satrix. (2013). Satrix 40. Retrieved March 14, 2013, from http://www.satrix.co.za/ products/satrix40.aspx

Saunders, M., \& Lewis, P. (2012). Doing research in business and management: An essential guide to planning your project. Harlow, UK: Prentice Hall.

Sharp, L., Mackay, G., Rankin, N., \& Aling, P. (2012). Are South Africa's CEOs overpaid? Labour Market Navigator 2012(Q1), 1-36.

Shaw, K.W., \& Zhang, M.H. (2010). Is CEO cash compensation punished for poor firm performance? The Accounting Review, 85(3), 1065-1093. http://dx.doi. firm performance? The Accounting

Shaw, P. (2011). CEO pay-performance sensitivity in South African financial services companies. MBA research report, Gordon Institute of Business Science (GIBS), University of Pretoria, South Africa.

Traichal, P.A., Gallinger, G.W., \& Johnson, S.A. (1999). The relationship between payfor-performance contracting and external monitoring. Managerial Finance, 25(9) 68-88. http://dx.doi.org/10.1108/03074359910766163

Van Blerck, T.G. (2012). The relationship between executive remuneration at financial institutions and economic value added. MBA research report, Gordon Institute of Business Science (GIBS), University of Pretoria, South Africa.

Van Rooyen, L., Du Toit, D.H., Botha, E., \& Rothmann, S. (2010). Artisan retention in an organisation in South Africa. SA Journal of Human Resource Management, 8(1), 1-8.

Veliyath, R., \& Bishop, J. (1995). Relationship between CEO compensation and firm performance: Empirical evidence of labour market norms. The International
Journal of Organizational Analysis, 3(3), 268-283. http://dx.doi.org/10.1108/ eb028832

Ward, M., \& Price, A. (2006). Turning vision into value: Corporate finance for nonfinancial executives. Pretoria: Van Schaik.

Warr, P., \& Fay, D. (2001). Age and personal initiative at work. European Journal of Work and Organizational Psychology, 10(3), 343-353. http://dx.doi. org/10.1080/13594320143000717

Weiers, R.M. (2010). Introduction to business statistics. (7th edn.). Boston, MA: South Western, Cengage Learning.

Wibowo, G., \& Kleiner, B.H. (2005). The duties of a chief executive officer. Management Research News, 28(2/3), 88-99. http://dx.doi.org/10.1108/0140917051078 5138 